\title{
You're Not Gay Enough: The Experiences and Challenges of LGBTQ Refugees During the Asylum Determination Process in Toronto
}

by

\author{
Allison T.E. Holder \\ BA, Dalhousie University, 2016
}

A Major Research Paper presented to Ryerson University in partial fulfillment of the requirements for the degree of

\author{
Master of Arts \\ in the Program of \\ Immigration and Settlement Studies
}

Toronto, Ontario, Canada, 2017

(C) Allison T.E. Holder, 2017 


\section{AUTHOR'S DECLARATION}

I hereby declare that I am the sole author of this Major Research Paper. This is a true copy of the MRP, including any required final revisions.

I authorize Ryerson University to lend this MRP to other institutions or individuals for the purpose of scholarly research.

I further authorize Ryerson University to reproduce this MRP by photocopying or by other means, in total or in part, at the request of other institutions or individuals for the purpose of scholarly research.

I understand that my MRP may be made electronically available to the public.

Allison Holder 
You're Not Gay Enough: The Experiences and Challenges of LGBTQ Refugees During the Asylum Determination Process in Toronto

(C) Allison T.E. Holder, 2017

Master of Arts 2017

Immigration and Settlement Studies

Ryerson University

\begin{abstract}
From much of the previous literature, it has been assumed that the IRB refugee determination system is inherently unfair to LGBTQ claimants, and that it demands queer refugees disclose a great deal of intimate personal information to meet heteronormative markers of gayness. Although these experiences still occur for queer asylum seekers today, the participants in this research pointed towards a shift in the IRB claim process. Overall, the participants recognized that the system is made and maintained by those who view the world through a heteronormative lens. Ultimately, the research pointed towards the fact that claimants have adapted to meet the expectations of the IRB's LGBTQ refugee determination system. Through the sharing of information amongst fellow claimants, service providers, and legal counsel, queer refugees have become outstanding social actors who have learned how to perform their 'queerness' to gain a positive IRB result that ensures their protection from their countries of origin. It is important to note that this does not mean that anyone who wishes to seek asylum in Canada can do so under the guise of LGBTQ identities. Instead, this category of refugees has always been and will remain valid, and claimants have learned to perform the aspects of their identity which meet the stereotypical demands of the IRB and other heteronormative Canadian systems.
\end{abstract}

Key words: $L G B T Q, L G B T Q$ refugees, LGBTQ asylum-seekers, refugee claimants, IRB, Canada, Toronto, immigration, SOGIE, social actors, heteronormative, waiting 


\section{ACKNOWLEDGEMENTS}

This major research paper would not have been possible without the participation and enthusiasm of the research participants. To Alex, Devin, Charlie, and Sam - thank you for giving up your time to speak to a first-time researcher because you believed in contributing to the literature on such an important topic. Your insight and honesty make this MRP what it is. The interview excerpts are by far my favourite part of this paper and I hope my words give your stories justice.

To Dr. Doreen Fumia, thank you for being such an incredible supervisor. You are by far the best professor I've ever had in my academic career and your willingness to take on the queer researchers helped to produce two important research papers. You challenged and pushed me beyond what I knew what I was capable of academically. When I didn't think I would finish on time, you encouraged me and kept me working. It is hard to express my full gratitude to you.

To Dr. Idil Atak, thank you so very much for acting as my second reader. Your perspective from a different academic background pushed me to expand on IRB Guidelines and analyze policy in practice. Thank you for encouraging me and getting me to the end of this MRP.

I must also thank Dr. Laura Eramian from Dalhousie University. It was from your encouragement and gracious recommendation that I ended up taking on a Master's program. My writing would not be where it is today without your assistance throughout my time at Dal, and this MRP represents an academic progression that you played a huge role in.

To my fellow ISS cohort, congratulations on the end of a successful year! I look forward to seeing where our lives will take us next. As special nod to Mia and Dayana who will continue to be important people in my life after graduation. I would also especially like to thank Trudie, my fellow queer MRP-er, for being such a rock for me throughout this process. Having you as a 
person to complain to, to laugh with, to panic with, and to drink with made this process so much easier. I am really proud of what we created.

To my friends outside of the academic bubble, thank you for putting up with me this past year. Bobby, I cannot imagine my life without you. You're much more than a roommate and you put up with the brunt of this project. Your encouragement and support got me through these last few months. Emma, I don't know what I would do without you as my best friend. There was never a time where I complained or cried too much, and you always remembered every single important day for me and wished me well even though you had your own crazy schedule to look after. I am so lucky to have you and Ben in my life. Graham, thank you for being the best 'brother' around. Your editing, check-ins and humour helped me immensely. Kate, I am so glad that we became closer over the past year. You are one of the kindest and most loyal people I know and you were there for me when I really needed it over the summer. Mal, although our relationship took on many different forms throughout my Master's, your presence and absence motivated me to complete this project. Regardless, you were always supportive of my academic success and I am grateful.

Finally, and most importantly, I have to thank my Mom and Dad. Words cannot express how grateful I am for your constant support, love, pride, understanding, and encouragement. You have always been there for me when others were not, and throughout the more challenging times in my life you have kept me upright and moving forward. It is both of your hard work ethics which made me believe that I could take on this level of higher education. I've always carried with me our mantra: 'You can be anything you want to be'. I'm amazed this academic rollercoaster is finally over. I think we can be proud as a family for what we have achieved, and maybe I can actually start looking after you two now! I love you so very much. 


\section{DEDICATION}

To my pre-teen self: your identity is resplendent. Never stop exploring. 


\title{
POETRY AS INSPIRATION
}

\author{
And I feel so alive, \\ so valid. \\ So queer. \\ And when we walk together \\ I am shouting \\ “didn't I tell you all along I was real?"
}

Why didn't you all think I was real?

-Beja Alisheva 


\section{Table of Contents}

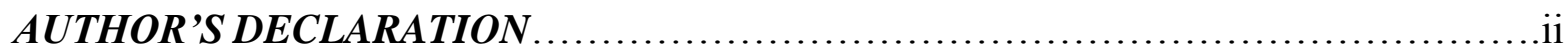

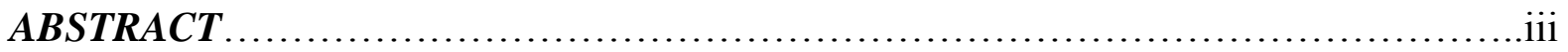

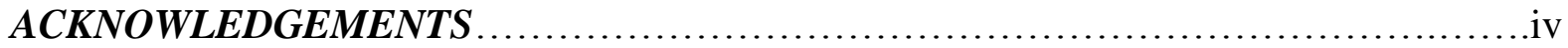

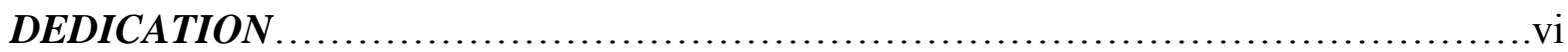

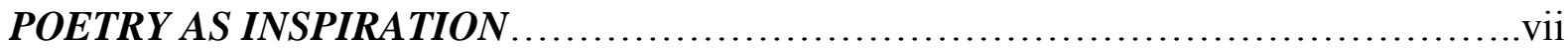

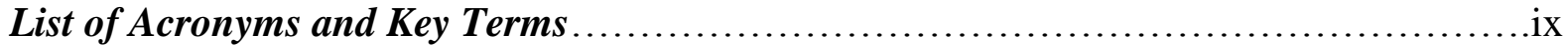

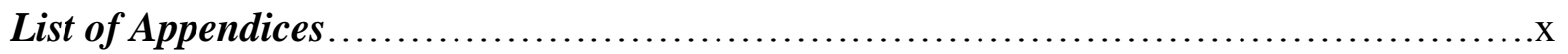

Chapter 1: Introduction ........................................................

Chapter 2: Methodology .................................................... 8

Chapter 3: A review of the current literature surrounding LGBTQ Refugees .................16

Chapter 4: The excerpts from research participants .............................24

What it's like to be LGBTQ in Croatia, Syria, and Jamaica .........................25

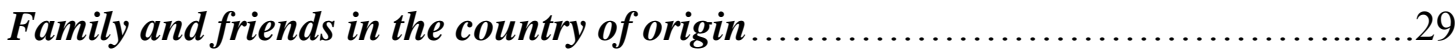

Arriving in Canada ................................................... 31

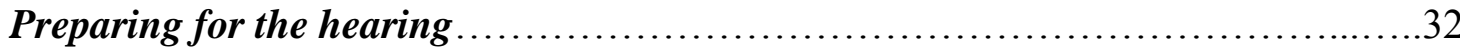

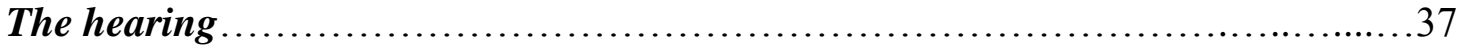

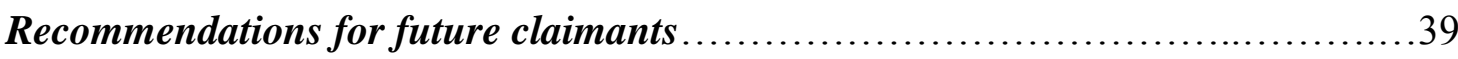

Recommendations for continued improvement of the system .....................41

Chapter 5: A Merging of Themes- Social Actors, Waiting, and Heteronormative Systems...44

Heteronormative systems, understandings, and actions ........................45

Waiting and waiting and waiting some more ..............................49

Social actors - when to hide and when to shout from the rooftops..................51

The future of the LGBTQ asylum determination process......................56

Chapter 6: A Changing System: The IRB's SOGIE Guidelines ......................................57

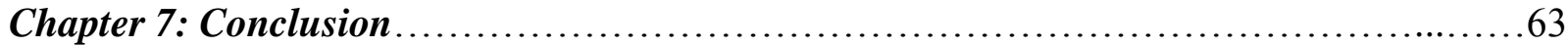

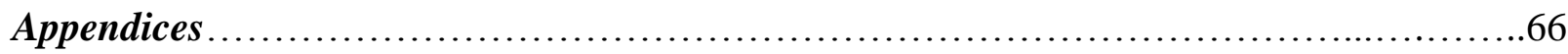

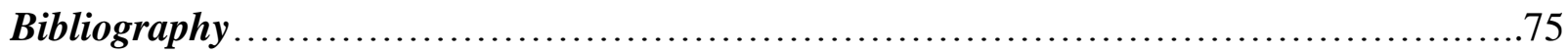




\section{List of Acronyms and Key Terms}

LGBTQ = Lesbian, Gay, Bisexual, Transgender, and/or Queer

SOGIE $=$ Sexual orientation and gender identity and expression

$\mathrm{IRB}=$ Immigration and Refugee Board

BOC $=$ Basis of Claim

*Please note that to vary the voice of the writing in this major research paper, the terms 'LGBTQ

refugee', 'queer refugee', 'SOGIE refugee'; 'LGBTQ claimant', 'queer claimant', 'SOGIE

claimant'; and 'LGBTQ asylum seeker', ‘queer asylum seeker', 'SOGIE asylum seeker' are all used interchangeably and represent the specific category of refugees who claim asylum in Canada based on fear of persecution for their LGBTQ identities. 


\section{List of Appendices}

$\mathrm{A}=$ Research recruitment letter

$\mathrm{B}=$ Research consent form

$\mathrm{C}=$ Research interview guides 


\section{Chapter 1: Introduction}

Forces of migration continue to intensify in an increasingly globalized and transient world. In many nations of the Global North, large influxes of immigrants and refugees have arrived due to a variety of economic and political forces, and there has also been an increase in refugee claims based on intimate, individual identities such as LGBTQ orientations. For example in 2015,1286 refugee claims based on persecution due to sexual orientation and gender identity were made to the Immigration and Refugee Board of Canada (IRB), and the IRB estimates that this number will only continue to increase each year (IRB, 2016). The definition of a Convention refugee, that is an individual with a "...well-founded fear of being persecuted for reasons of race, religion, nationality, or membership of a particular social group or political opinion...", comes out of the United Nations 1951 Convention and Protocol Relating to the Status of Refugees (UNHCR, 2017:14). Since the first Convention refugee was granted this status based on persecution of their LGBTQ identity in 1991 in Canada, and in 1993 when the Supreme Court of Canada ruled in AG v Ward that sexual orientation would be included in the parameters of a particular social group, the Immigration and Refugee Board has normalized a specific understanding and treatment of this category of refugees (Fobear, 2014). Unlike some other types of refugees (i.e.: economic, political, environmental, conflict, etc.), a refugee claim based on sexual orientation and/or gender identity and expression (hereafter referred to as SOGIE in accordance with IRB terminology) has become one of the most challenging categories of 'refugeehood' to demonstrate. Although their claims are still challenging, the category 'conflict refugee' can often demonstrate persecution based on citizenship in a country which faces civil war, or the 'environmental refugee' can often demonstrate a need for resettlement due to environmental changes that destroyed their home. Further, as demonstrated in the United Nations 
definition of a Convention refugee, sexual orientation and gender identity are not listed specifically in the grounds for protection from persecution (UNHCR, 2017:14). A SOGIE refugee can only state that they are LGBTQ and work to prove that their claim is legitimate. Due to the inherently personal and subjective nature of SOGIEs, claiming asylum based on persecution for being queer (a term used to describe those under the LGBTQ umbrella in my research) has become one of the most common types of attempted false claims seen at the IRB (Fobear, 2014). It is not enough for a SOGIE claimant to state that they are queer and feel threatened in their country of origin due to their sex and gender identity in order for them to be granted asylum in Canada. Instead, the IRB requires that LGBTQ claimants prove their 'gayness' during their claim beyond a reasonable doubt to the IRB member (LaViolette, 2013).

For many individuals who migrate to Canada and claim asylum from countries that persecute their LGBTQ identities, Toronto is positioned as a metropolitan, multicultural, accepting, and diverse 'safe-haven' (Canada Research Team, 2015). In a project by the Canada Research Team at York University, it was determined that the Greater Toronto Area (GTA) settles approximately one-third of all newcomers to Canada each year (2015). The Church and Wellesley Lesbian-Gay Village is framed as a thriving LGBTQ community with services and venues, including organizations which cater to the needs of LGBTQ immigrants, which are deemed to welcome the open expression of unique sexual orientations and gender identities (Nash, 2013). Aside from this well-known Village, neighbourhoods throughout the city host queer spaces as they are "defined and created through social interactions and particular events... and are thus enacted by social actors with different identities and agendas" (Bain et al., 2015). From this, Toronto is now considered by many to be the primary destination for LGBTQ newcomers and refugees to Canada (Canada Research Team, 2015). As many LGBTQ refugees 
arrive from countries of origin which persecute people based on their sexual orientations or gender identities outside of the heteronormative and male/female dichotomy, Toronto purports to offer the safe and welcoming space desired by LGBTQ asylum seekers. For example, in many Caribbean countries, the discourse surrounding Toronto as a destination for queer asylum seekers maintains that the city is the best place for settling as LGBTQ due to the large queer Caribbean community and the many resources and service organizations available (LaViolette, 2013). Although it may not always occur in the Village, queer spaces do exist in the GTA for various ethnocultural communities (Canada Research Team, 2015).

My intention in this research is to tell the stories of queer refugees who arrive in Toronto and seek asylum based on their LGBTQ identities. There are many valid queer refugees, and the number of this category of refugees continues to increase (IRB, 2016). These newcomers bring with them unique histories and face specific challenges prior to, during, and after their refugee claims. The validity of their queer identities has always existed, and I do not wish to challenge this or focus on those who attempt false refugee claims under the guise of LGBTQ identities. Instead, my research aims to demonstrate how asylum seekers' interactions with and through Canada's heteronormative refugee determination system, alongside a lengthy bureaucratic process that places claimants in limbo and forces them to wait, has required them to adapt to meet the demands of the system. Earlier this year, Guidelines were released for SOGIE refugees by the IRB which demonstrate the recognition of the needs of this category of refugees (IRB, 2017). At the same time, the repercussions of the above described system continues to affect the experience of LGBTQ asylum seekers (Canadian Council for Refugees, 2017). In response to these pressures, LGBTQ claimants have learned how to best perform their 'gayness' and behave to meet the demands of the Canadian asylum determination system in order to secure protection 
from persecution based on their sexuality and gender identity. In short, I aim to demonstrate how the phrase 'you're not gay enough' is rarely, if ever, used or internalized by queer refugees, yet the system continues to assume that LGBTQ claimants are 'not gay enough' until they prove that they are truly queer.

As someone who self-identifies as a member of the LGBTQ community, I have personally experienced the challenges and contradictions involved in expressing sexual orientation. Due to societal norms, a general assumption is made by individuals in society (not by all, but by many) that the people one encounters in their life are assumed to be heterosexual until they declare an alternate sexual orientation. Although this presents its challenges, I have 'come out' at a time and in a generally accepting social landscape which supports and creates space for LGBTQ individuals in Toronto. Further, the fight for the rights of LGBTQ peoples in Canada shaped the legislation which provides me with the privileges I benefit from today. In 1996 the Canadian Human Rights Act was changed to include sexual orientation as a prohibited grounds of discrimination, creating legal protection for LGBTQ Canadians (Government of Canada, 2017). In 2002 the Federal government ruled to accept same-sex marriages under the law even though they were up against a great deal of opposition from citizens and provincial governments (CBC, 2015). Although I recognize the privilege I experienced in my fairly seamless coming-out process, the decision to express my sexual orientation as a cisgender woman was not one I took lightly. My ability to hide my lesbian identity from my friends and family was made easy during my undergraduate degree while I lived in Halifax, NS, as this transient time in my life allowed me to disguise my interest in women as experimentation and bicuriosity alongside absolutely terrible luck with men. 
It was only when I returned to Ontario after graduating from university that I realized I had to confront the complexity of my identity; I was performing a heteronormative persona for everyone else around me and was not, pardon the cliché, being true to myself. My parents first reacted with lines such as "well I hope I still get grandkids" and "are you sure you're not just bisexual?" when I came out to them in our living room. When I ran into an old high school classmate at a local bar who had heard about my gayness through the grapevine, he awkwardly asked me if, from now on, I would be "playing for the other team". Due to my small-town upbringing, and despite the fact that I am an adult, my parents still expect me to be careful about who 'we' tell about my sexual orientation. I easily comply since I do not feel safe walking down the main street of my small community holding hands with a partner. Although these comments and experiences pale in comparison to those of an LGBTQ asylum-seeker, they demonstrate the need to hide identities - if it is possible to pass in order to seek the safety and comfort provided by performing a heteronormative identity. Further, they also demonstrate why I have become interested in the narrative of the LGBTQ asylum seeker; I wonder what it would be like to live in an environment where my sexual orientation creates fear of violent persecution, complete social alienation, and the need to flee my country of origin. My research is a social justice project which is rooted in the altruistic goal that it can point to the unfair contradictions, heteronormative expectations, periods of waiting, and social performances required of LGBTQ refugees.

As explained above, the title of my research considers both the common assumptions made about LGBTQ asylum seekers and also the pressures felt by the claimants themselves; you're not gay enough. Much of the extant literature on LGBTQ refugee claimants, as will be discussed in Chapter 3 of this paper, has been highly critical of the queer asylum process in Canada (LaViolette, 2013). Among headlines and academic articles, the phrases "re- 
victimizing", "putting their sexuality on trial", "heteronormative standards of LGBTQ identity", "a lifetime of hiding followed by a complete void of faith", and "persecute their identity once more" have emerged through the discourse surrounding LGBTQ refugee determination (The Globe and Mail, The Toronto Star, Egale, CCR). When I first began this research, I assumed that all of the literature I reviewed and the interviews I conducted would lead me to the same conclusion: the refugee determination system in Canada is disproportionately unfair to queer asylum seekers in comparison to other categories of refugees and, more specifically, that nothing was being done to change it. Although the above cited headlines and my original assumptions still exist for LGBTQ refugees, my research is occurring at a time of great change. As mentioned above and discussed in Chapter 6 of the research, recent Guidelines have been released by the IRB which pertain specifically to the unique needs and challenges faced by LGBTQ refugees. These guidelines have emerged out of the discourse which continually expresses that queer asylum seekers are treated unfairly and put on trial for their intimate sexual orientations and gender identities. Further, prior to May 2017, IRB board members did not have any specific Guidelines or policies which pertained to the needs, interpretation, and treatment of LGBTQ refugees. My research does not aim to focus solely on the fact that the IRB has continually revictimized and placed an unfair burden on LGBTQ refugees to prove their identity; previous research has already questioned and challenged the LGBTQ claimant experience. Instead, my research aims to present a balanced approach to the refugee determination system by examining the dominant discourse surrounding the treatment of LGBTQ refugees alongside the potential for change with the recent IRB SOGIE Guidelines. In Chapter 3 I review the current literature on LGBTQ refugees in Canada, and also analyze the Vulnerable Persons Guidelines 8 by the IRB which stood as the sole directive for board members in regards to LGBTQ asylum seekers until 
the new Guidelines were released in May 2017. In Chapter 4 I explore the narratives of both successful LGBTQ Convention Refugees and an immigration lawyer who specializes in SOGIE claims. In Chapter 5 I analyze the adaptations that this specific category of refugees have taken on to meet the demands of the system. In Chapter 6, I review the IRB's recent Guidelines specific to the needs of LGBTQ claimants. I turn now to the methodology used for the research in this MRP, including the process for conducting interviews. 


\section{Chapter 2: Methodology}

“...conditions that hold for any knower, regardless of her or his identity, interests, and circumstances (i.e., her or his subjectivity) - could conceivably be discovered only for a narrow range of artificially isolated and purified empirical knowledge claims, which might be paradigmatic by fiat but are unlikely to be so 'in fact'..." (Code in Alcoff \& Potter, 1993:15).

From my academic training, qualitative research methods act as the best possible way to understand the lived experiences of individuals who had to flee their countries of origin due to their sexual orientation and gender identity. As explained by Corbin and Strauss, qualitative research can be described as the practice in which a researcher "collects and interprets data, making the researcher as much a part of the research as participants and the data they provide" (2008:20). This distinction is what makes qualitative research useful for interpreting the nuances and narratives of groups very different from the researcher. Qualitative methods allow the researcher and participants to piece together an intimate and individual narrative, bringing to life and into academic discourse the lived experiences and perspectives of the research subjects. Additionally, the method allows for and recognizes the roll of and interaction between both the researcher and participants. Hartsock explains, "rather than getting rid of subjectivity or notions of the subject...we need to engage in the historical, political, and theoretical processes of constituting ourselves as subjects as well as objects as history" (quoted in On, 2003:88).

For these reasons, qualitative research methods, grounded in queer and feminist theories, are used throughout this research. In this way, the perspectives of a highly marginalized group is given voice. That is to say that I as the researcher, am intensely aware of my own positioning and 
how my perspective and privilege influences my understanding and interpretation of LGBTQ refugee claimants' experiences. To echo the quotation at the beginning of this chapter, I am someone who identifies as a gay woman and as a member of the LGBTQ community, and recognize the power relations embedded in my subjectivity as a white, upper middle class, cisgendered female with an accepting family and community, and life-long Canadian citizenship. Although I have some sense of queer marginality and struggle, my story does not reflect the experiences of the subjects in my research. So, what gives me the right to interrogate stories so different from my own and how will I do this in a way that allows space for marginalized voices when I do not share these experiences? It is my hope that being aware of my positioning will allow for a more authentic telling of the research subjects' stories.

As noted, my research employs qualitative methods through in-person one-on-one interviews between the participants and I. Drawing from Strauss' approach to analysis and research strategies, qualitative research methods have allowed for continually challenging "the assumptions about the inevitability of contingencies, the significance of process, and the complexity of phenomena" in order to "locate action in context, to look at action and interaction over time, and to examine action and interaction in routine as well as problematic situations" (Corbin \& Strauss, 2008:22). In short, the aim of my research is to make the strange familiar and the familiar strange to ensure that at every step of the literature review and from every answer given during the participant interviews that pre-conceived ideas about the LGBTQ refugee claim system were questioned and challenged. From hearing the participants' stories firsthand through questions and answers, the research works to act as a vehicle to convey the LGBTQ asylumseekers' personal narratives. Specifically, the interviews aimed to interrogate the asylum hearing process, mindful of how LGBTQ claimants are required to prove their sexual orientation and/or 
gender identity and legitimate relationships through highly personal accounts, images, messages, and testimonies by bystanders and partners. Without having lived through those experiences firsthand, I did not feel as though a review of the current literature and statistical data or an anonymous questionnaire would allow for the participants' stories to be heard and for their narratives to contribute to the understanding of the current LGBTQ refugee determination process in Canada.

The research was conducted through one-time individual interviews with three LGBTQ Convention Refugees who had completed their Immigration and Refugee Board (IRB) hearing and were granted refugee status. In addition, I interviewed one Immigration and Settlement lawyer who regularly represents LGBTQ refugees during their IRB hearing as my key informant. The research participants were recruited through community-based LGBTQ newcomer support services in Toronto and also through outreach to LGBTQ refugees and service providers who had been profiled by the media and were open about their status and story. A snowballing technique, that is where connections are employed across social networks to access specific populations, was utilized to contact other potential participants as the LGBTQ refugee community in Toronto is fairly small and connected (Browne, 2007:47). The LGBTQ refugee participants had to be at least 18 years of age, been granted Convention Refugee status, and demonstrate their ability to converse in and comprehend English. No individuals who were either interested in claiming asylum, were in the process of claiming asylum, or who had their claims denied by the IRB were eligible to participate in the research. This was due to ethical considerations; I did not want to jeopardize an individual's current or prospective claim by exposing aspects of their experiences and stories. This was especially important because individuals who were planning to or in the process of making claims could have used the 
research and their participation as evidence of their LGBTQ status during their hearing, jeopardizing the research and challenging confidentiality. It is also common that LGBTQ claimants need sponsors during their hearings who can write letters of support to vouch for their participation in the LGBTQ community. I did not want to put myself, the research, or the participants in that position.

To recruit participants, I approached potential subjects in person and described the research project and its aims. If the potential informant expressed interest in participating, I provided the individuals with either a hard-copy of the research recruitment letter or an electronic copy of the letter through email (see Appendix A for recruitment letter). After the potential informants had the opportunity to review the recruitment letter, those who agreed to participate set up a date and time with me for the interviews. All participants were sent an electronic copy of the consent form one week prior to the interview and were reminded that their participation was completely voluntary and that they could withdraw their consent anytime leading up to, during, or one week following the interview (see Appendix B for consent form). All of the communication between the participants and I prior to the interviews was conducted through email.

Prior to the start of the formal interview and recording, I reviewed the consent form in person with the participant to ensure their complete consent and understanding of the research project. I reminded the participant again that their consent could be revoked anytime during the interview and up to one week following the interview. The participant and I signed the consent form together, and we each retained a copy. The interviews lasted from one and a half to two hours in length, and were made up of pre-determined questions that I created (see Appendix C for interview questions). The questions had an open-ended element which allowed me to prompt 
participants for further information or clarity, but the question content never strayed from the pre-approved questions. The interviews were conducted in study rooms on the Ryerson University campus to ensure privacy and confidentiality. The exception to the interview setting occurred twice during the research; one participant felt more comfortable meeting at a local coffee shop, and the other participant requested the interview be held at their private office for scheduling and personal convenience reasons. All of the interviews were audio recorded, and immediately following the interviews were transcribed, with notes of emphasis made on the interview guide for my later review. I collected and stored the participants' names, telephone numbers and email addresses due to the intimate nature of the interview content. All personal identifiers were stored separately from the interviews in a password-encrypted document, ensuring that the interview transcriptions would not be tied back to the individual participants. All physical copies of consent forms and research notes were stored in a locked filing cabinet in my office.

In order to analyze the interview data, I first identified three main themes which emerged in both the interviews and the pre-existing literature. These themes were:

- refugee claimants are adaptable social actors (coded as \#1)

- an emphasis on the universal experience of waiting throughout the claimant process and its unique impact on LGBTQ claimants (coded as \#2)

- refugee claimants' interactions with and through heteronormative systems (i.e.: the IRB claim process, legal counsel, service providers) in Canada (coded as \#3)

The above stated numerical codes were taken and applied to both the interview excerpts and the compiled existing research. I organized all of these findings into a chart to aide in deciphering the data. When analyzing the current literature regarding LGBTQ refugees, I looked through 
academic and statistical databases with keyword computer and library searches alongside a focus on certain authors who have contributed greatly to this topic. This literature review was conducted to inform the areas of focus for the research and allow the existing literature to help tell the research participants' stories. Additionally, the interviewees were given gender-neutral pseudonyms in order to keep track of their responses and ensure the equitable representation of all the participants' voices. The pseudonyms correspond as follows:

- Alex $=$ the Convention refugee from Croatia

- Devin $=$ the Convention refugee from Syria

- Charlie $=$ the Convention refugee from Jamaica

- Sam = the Immigration and Settlement lawyer

The pseudonyms were kept gender-neutral to ensure the utmost degree of confidentiality for the research participants. It is important to note that Alex gave consent for he/him/his pronouns to be used in his interview excerpts. All of the other research participants are referred to using they/them/their pronouns.

I was aware of the potential risks associated with participation in the research and I made those risks clear to participants to ensure that they felt supported and safe. First, I asked participants questions about their personal experiences of seeking asylum due to their LGBTQ identity and encouraged individuals to discuss circumstances of persecution and trauma in their countries of origin. The interviews also included questions about their claim and hearing process once they arrived in Canada. All of these topics had the potential to trigger participants and make them feel anxious, upset, uncomfortable, angry, and in the worst case, cause re-traumatization. To mitigate these risks, I provided the participants with a list of community resources and counseling services specific to their status prior to the interview. The participants were reminded 
that they could decline to comment on any topics or to answer specific questions if they did not want to. Second, I recognized that the LGBTQ community, especially that of LGBTQ refugees, is quite small in Toronto. Many of the individuals recruited for the research and the participants in the project were known to each other, and certain stories or descriptions of circumstances had the potential to be traced back to the research participants. To minimize this risk, I made clear to the participants that all of the data from their interviews would be presented anonymously in the written research findings. In addition to the use of pseudonyms, I removed all factors which could cause individuals to be identified including but not limited to their appearance, occupation, school program, location they inhabit in the city, a specific town or city in their country of origin, and interactions with specific community organizations.

To outweigh the potential risks and limitations of the research, and also to encourage participant involvement and to maintain the momentum of the project, the potential benefits of the project were kept at the forefront of my motivations. During my preliminary research of the topic, I found a large gap in the literature representing the voices of LGBTQ refugee claimants in Toronto. Further research is needed to help better understand and support the evolving needs of this very specific, marginalized, and often voiceless group which had already experienced immense trauma in their countries of origin. The research acted as both a way for the participants to articulate their refugee or IRB hearing experience, expressing the challenges and needs they felt during the process, and also as a way for future claimants to be better supported and understood throughout the continued changes in the system. As the number of LGBTQ asylum seekers to Canada increases each year, substantial research must analyze and challenge the current refugee determination system (IRB, 2016). This research is constructed in hopes that it may form the basis of future research and contribute to future policy decisions. 
Now that the reasoning for using qualitative research methods has been provided and a detailed account of the research methodology has been explained, the following chapters will tell the story of the research participants. To begin, the next chapter will analyze the existing literature on LGBTQ refugee claims in Canada. It will interrogate the existing themes found by other researchers and point towards the gaps in the research which motivated this project. 


\section{Chapter 3: A review of the current literature surrounding LGBTQ Refugees}

From an analysis of the current literature surrounding LGBTQ refugees' experiences, there emerges some common themes both observed by academics and expressed by refugee claimants and service providers. These commonalities include how LGBTQ refugees face the assumption of being bogus, queue-jumping and inauthentic refugees, how the asylum seeking process forces claimants to perform to meet the standards of LGBTQ identities as set out by the IRB and Western heteronormative standards, how refugees make claims through and up against a deeply heteronormative system, how refugees have been required to present concrete proof of their LGBTQ histories and practices, and how claimants often face cultural insensitivity and embarrassment during their claims. Many of these commonalities are founded in the lack of directive or Guidelines for the IRB's treatment and interpretation of LGBTQ refugees up until May 2017. Following a review of the current literature, this chapter will also review the IRB's Vulnerable Persons Guidelines to analyze the IRB's perception of queer asylum seekers prior to the release of the new Guidelines.

In a highly globalized and fluid world condition, the free movement of peoples represents the opportunity for self-betterment and ability to choose one's ideal life circumstances, versus the threat to sovereignty and abuse of social service systems. A 'genuine' asylum seeker is someone with a strong claim and is framed as a passive and helpless victim in need of protection. Whereas an "undeserving asylum seeker" is one who is viewed as having figured out how to work the system in refugee accepting nations by making a false claim based on a fear of persecution on the grounds which many deem as questionable (Vertiachykh and Lindroth, 2014:9). More often than not, LGBTQ asylum claimants are framed as bogus refugees; sexual orientation is a self-proclaimed identity which often lacks the visible or documented proof 
typically required of asylum claimants (Egale, 2017). Unlike a claimant seeking asylum on the grounds of membership to a minority ethnic, religious, or political group, LGBTQ individuals base their claims solely on sexual orientation and gender expression. The United Nations definition of a Convention refugee does not outright specify LGBTQ orientation as membership to a social group (UNHCR, 2017). This status is highly personal and typically psychological, making it incredibly challenging for claimants to prove authenticity. In many cases, LGBTQ asylum claimants come from countries of origin with highly repressive anti-LGBTQ regimes which can make articulating an LGBTQ identity challenging and uncomfortable. Further, retrieving documents or letters of support to corroborate LGBTQ orientation is near impossible when claimants originate from countries with anti-LGBTQ policies and social expectations.

The terms 'bogus asylum seeker' and 'queue jumper' have become prominent in the Global North migration discourse. These labels promote the criminality of LGBTQ asylum seekers in Western nations, presuming from the onset that the claimants are lying about their sexual orientation in order to gain refugee status. Unfortunately, many claimants have faced years of persecution and psychological trauma prior to their arrival in their country of asylum. These experiences often prevent individuals from feeling as though they are safe to tell their stories, and the strict timelines on the asylum seeking process do not allow time for integration into LGBTQ communities or access to counselling (Mule \& Gates-Gasse, 2015:16). Ironically, many claimants migrate to countries such as Canada to escape the criminality surrounding their sexual orientation, yet these asylum seekers are unable to escape their perceived 'moral failings' due to their sexuality or gender identity once they arrive in the Global North (Bieska, 2013:26). Instead of being believed for their self-declaration of LGBTQ orientations, claimants are labelled 
as 'queue-jumpers' who must work to validate their sexual orientation before their asylum claims are deemed truthful.

Asylum seekers constantly have to engage in performances for the identities deemed appropriate to the social space they inhabit. Often individuals begin to recognize their sexuality from the age of ten to twelve years old, meaning that they have been living a "double life" for years by the time they seek asylum from their countries of origin (Mellquist, 2014:42). Some have lived in or have been forced into heterosexual relationships to prove to their families, communities, or even themselves that they are not gay. Any homosexual activity in their life has been repressed or carefully concealed, and a constant fear of being discovered has followed them since the time where their sexual and independent adult identities were shaped. In Mellquist's fieldwork entitled Officially Categorized Queers, the researcher notes how the process of hiding, or as Erving Goffman and Judith Butler would call performing, becomes deeply embedded in the claimants' everyday lives and practices. One informant in this study found the requirement to express their sexuality openly in their country of refuge to be very challenging. The individual actually continued to attempt to be in a heterosexual relationship in their country of asylum, and found that transitioning from being forced to hide for so long into an expected overt expression of honest sexuality created a practice of "reverse covering" (Mellquist, 2014:43).

Western society holds an obsession with being able to recognize and categorize individuals into the preconceived notions of identity characteristics. As determined by Goffman (1959) our identities are socially, culturally, and politically recognized and reaffirmed throughout our interactions with society on a daily basis. Specifically, we all go throughout life producing and portraying certain identities which coincide with the situations we are in and the 
people we are interacting with (122). Goffman explains how unpredictable or unclear identities make society uncomfortable because:

...information about the individual helps to define the situation, enabling others to know in advance what [they] will expect of them so others will know how best to act in order to call forth a desired response from [them] (1959:120).

When someone's identity is unclear or very different from the norm, other members of society do not always know how to interact with them and deal with the situation. For example, in the context of this research, when an individual openly displays their sexual orientation or gender identity through their everyday interactions and presentation as non-heteronormative, society immediately recognizes their identity expressions because they differ from the heteronormative. As was discussed above, this sense of difference can have varying degrees of consequences for LGBTQ individuals depending on the geographic and social positions they inhabit.

As previously mentioned in the paper, LGBTQ claimants face a highly Westernized coming out trial when they choose to seek asylum on the grounds of sexual orientation. After years of heteronormative performance, fearing authority, and facing persecution due to their innate sexuality, LGBTQ individuals unsurprisingly have difficulty being open about their sexuality. As explained by Katherine Fobear in Queer Settlers, LGBTQ asylum seekers have to "work with and against Western narratives...in order to be recognized as members of a particular social group" (Fobear, 2014:30). To further this idea, Lubheid argues it is important to remember that the Western promise of coming out coincides with the "romance of individual liberation" where the "closet is a collaborative social formation" (2012:182). This Western hegemonic notion frames coming out as a freeing process and assumes that this experience is universal for and welcomed by all. The credibility of LGBTQ asylum claims is often based on an individual's 
coming out story in either their country of origin or in their visits to liberal Western societies. Without the narrative of coming out to back up an asylum seeker's claim in a country with an established community of LGBTQ individuals and allies, claimants are often deemed as frauds and are met with great suspicion from immigration officials (Mellquist, 2014:44). Further, the normative Western LGBTQ identity is framed through a consumerist notion of a certain appearance, specific types of clothing, a recognizable diction, and social activities. For example, Mellquist met claimants who were questioned regarding the authenticity of their 'gayness' due to the fact that they never went to gay bars in their country of asylum and did not engage in sexual activities with individuals known in the gay community (2014:44). This condition of authenticity is unlikely to be found in an individual who has worked to hide their sexuality.

In an ethnographic study by Berg and Millbank, it was found that few claimants were able to present a partner from a current same-sex relationship, and further found that even fewer claimants had been in public same-sex relationships or had past partners who could vouch for the authenticity of their claim due to social and cultural norms. Claimants were asked to produce documentary evidence of their sexuality through photos of lovers, with transcripts of texting and email conversations, proof of membership to lesbian and gay community groups, or through testimony by family members and close friends (Berg and Millbank, 2012:197-8). More often than not, LGBTQ asylum seekers were unable to produce any of the above criteria to support their claims. Paradoxically, Berg and Millbank found that when they were able to produce some proof of their sexual orientation, it was intensely questioned and often regarded as self-serving and staged (2012:198). From this, even claimants with copious amounts of documentary evidence alongside a current same-sex partner were framed as bogus and illegitimate from the onset of the asylum seeking process. 
Cultural sensitivity is an incredibly important aspect of LGBTQ claimant procedures and interpretations. For example, many LGBTQ individuals have shown to be incredibly reluctant to openly talk about their sexuality in front of an interpreter that might be from the same ethnic or religious group (Mellquist, 2014:45). This is due to the fact that they may feel afraid of this person's reaction to and judgement of their claim, and worry that their entire ethnic or religious community in their country of asylum may find out about their sexual orientation. Further, it is sometimes deemed completely culturally inappropriate to speak to the opposite sex about one's sexuality, and other claimants have expressed how they were uncomfortable with discussing sexual activities in front of older individuals (Hojem, 2013:21). In one case, Hojem explained in the article Fleeing for Love how a LGBTQ young female felt uncomfortable making eye contact with her older male interpreter, and from this her claim was deemed to be a fraud because her lack of eye contact indicated that she was lying (2013:22). In an already rigorous and invasive claimant interview process, individuals are also required to push aside cultural norms in order to prove the validity of their claims. From this it becomes clear why some claimants are deemed to be inauthentic and not honest enough in the exposure of their LGBTQ lifestyles. Ultimately these descriptions of the LGBTQ asylum determination process in Canada demonstrate how claimants "have to inferiorize and pathologize their ethnic, religious, or cultural communities in order to fit into Canada's national fantasies...to separate the racism, sexism, and homophobia in the global South from the 'progressive', 'developed', and 'civilized' global North (Fobear, 2014:30).

From this review of the current literature surrounding LGBTQ refugees in the Global North, it is clear why the system and its processes have been widely critiqued by academics, service providers, immigration lawyers, and the refugee claimants themselves in Canada. Alex, Devin, and Charlie all went through their claims, and Sam represented numerous refugee 
claimants, under the system prior to the introduction of the new SOGIE Guidelines and their experiences documented here reflect circumstances described in this literature review. Prior to the release of these Guidelines, the only direction for IRB board members in the interpretation and treatment of SOGIE refugee claimants was in the Vulnerable Persons Guideline 8. Published in December of 2006, the Procedures with Respect to Vulnerable Persons Appearing before the $I R B$ aimed to "provide procedural accommodation(s) for individuals identified as vulnerable persons by the IRB" (IRB, 2016). Vulnerable persons are defined in the Guidelines as those "whose ability to present their cases before the IRB is severely impaired" due to "traumatic experiences that resulted in some degree of vulnerability" (IRB, 2016). Under Section 2.1 of the text, sexual orientation and gender identity are listed as potential grounds for being defined as a vulnerable person by the IRB, yet no further explanation or analysis of how or why an LGBTQ individual would be defined and what it would mean for their claim is provided (IRB, 2016). In order to be considered a vulnerable person, the claimant's lawyer has to submit an application on their behalf prior to their hearing. At the same time, an application for vulnerable persons status does not mean that the IRB will grant this status or that it will impact the proceedings (Egale, 2017). At the very end of Guideline 8 in Section 16, LGBTI (the acronym used by the IRB in the Guidelines) individuals are defined and board members are alerted to their needs by the following brief explanation:

Lesbian, gay, bisexual, transgender and intersex (LGBTI) individuals may have suffered negative experiences due to homophobia in their respective countries of origin, most specifically discrimination, bullying, ostracism, violence, sexual assault, and so on. The IRB has been sensitive and will continue to be sensitive and alert to the impact that these particular circumstances may have on some LGBTI individuals... (IRB, 2016). 
Although Section 16 recognizes LGBTQ asylum seekers as a distinct group with unique challenges and experiences, it also fails to provide any guidance to IRB board members in regards to what they should be sensitive to and how their experiences could impact their claim and the hearing process. In short, the Vulnerable Persons Guidelines were not enough.

In the following chapter, many of the themes from the literature review alongside the lived experiences of only interacting with the system through the Vulnerable Persons Guidelines are echoed during the interviews with the research participants. It is important to note that as mentioned during the introduction to my research, the IRB released new SOGIE Guidelines in May of this year in an attempt to alleviate some of the commonalities experienced by LGBTQ refugee claimants and service providers. As explained, these Guidelines had not been implemented at the time of my interviews and therefore only the potential outcomes from the Guidelines will be discussed in Chapter 6. 


\section{Chapter 4: The excerpts from research participants}

The qualitative interview component of this research with three refugees and one key informant was by far more rewarding and insightful than any review of existing literature or refugee statistics. The main aim of my research is to expose the human element of an LGBTQ refugee claim and provide a platform for both the claimants' and counsel's narratives of their experiences. Their immense insight helped to in part support the common critiques made of the LGBTQ asylum seeking process as discussed in the literature review, and also promote the continued improvement of the system as attempted by the IRB's SOGIE Guidelines. In this chapter I aim to present an analysis of the LGBTQ refugee determination system in Canada. I attempt to represent the human element of the experience instead of the assumptions continually made about the system.

The following analysis of the interview findings has been divided into sub-sections to allow for an organized and linear presentation of the LGBTQ refugee claimant experience. These sub-sections were easy and logical to create due to the commonalities between the interviewees' narratives. First, data regarding the lived experiences of claimants in their countries of origin is presented, followed by a look at the treatment and persecution they faced from their family and friends. I would like to note that although these experiences did not occur in Canada or during the IRB hearing, it is important to include the participants' recollections of persecution and social expectations in their countries of origin in order to understand the unique experiences and validity of LGBTQ asylum seekers. The next two sections highlight their initial arrival in Canada and their time spent preparing for their hearing, documenting their experiences prior to having Convention Refugee status. Subsequently the following section explains the IRB hearing in detail from the perspective of the claimants and counsel. Finally, the last two sections provide 
recommendations for both future claimants and the continued improvement of the system directly from the claimants and service providers.

\section{What it's like to be LGBTQ in Croatia, Syria, and Jamaica}

In the past decade, there has been a significant surge in the recognition of and legal protection for LGBTQ individuals both in the Global North and the Global South. In many parts of the world, expressing sexual orientation which differs from the heteronormative, that is anything other than male to female relations, is both common and widely accepted. At the same time, 75 countries, that is one-third of the countries in the world today, continue to criminalize same-sex sexual activity and identification. In these countries, LGBTQ persons are considered to be "illegal, immoral and criminal, and deemed to not deserve the same legal protections as other people" (Carroll \& Itaborahy, 2016:28). It is important to note that these numbers have improved in the past decade where in 2006, 92 countries criminalized same-sex sexual acts. This represents the decriminalization of 17 nations (Carroll \& Itaborahy, 2016:8). Still, many countries subject LGBTQ individuals to "risks, abuses, harassment and human rights violations on the basis of their gender and sexuality" (Canada Research Team, 2015:7). The profound discrimination against LGBTQ individuals in some parts of the world directly translates into everyday challenges. Even in countries where homosexuality is legal, social norms can make openly identifying as LGBTQ unbearable. For example, LGBTQ people are often subject to discrimination through a lack of access to housing, employment, health and education, and often face eviction from their homes by landlords when their identities are exposed (Canada Research Team, 2015:7). Individuals regularly face persecution by the media and tabloids who seek to out LGBTQ persons and contribute to negative discourses surrounding these sexual orientations. There have been numerous reports of lesbians who are attacked and raped for the purpose of 
"corrective rape" by men where social stigma surrounding LGBTQ individuals deems such acts as justifiable for the safety and sanctity of communities (Canada Research Team, 2015:8-9). Further, research has also shown that LGBTQ individuals face less visible forms of violence and persecution. For example, governments in many nations struggle to provide protection to individuals from family members, their communities, and authority figures during the mundane and nuanced parts of everyday life (Mule \& Gates-Gasse, 2014:6).

My research explored Convention refugees from countries where it was both legal, in Croatia, and illegal, in Syria and Jamaica, to identify as LGBTQ and participate in same-sex relationships and marriages (ILGA, 2017). In Croatia same-sex partners are recognized but not protected under the law, and in Jamaica and Syria outed LGBTQ individuals and couples can face up to 14 years in prison (ILGA, 2017). To begin, although Alex from Croatia could participate in society as an openly gay male without legal ramifications, the social and religious interpretations of homosexual men make being openly LGBTQ dangerous and alienating. As explained by Alex, "socially it's not acceptable. You still have to be in the closet and you have to pretend that you're not who you are" when I asked how the legalization of same-sex relationships had changed Croatia. When asked what would happen if you tried to be openly gay, Alex explained:

...if I wanted to hold my partner's hand and go walking down the street all la-de-da, you can be sure that someone is going to punch you. I have a [lesbian] friend of mine, she still lives there, and I can't remember how many times she has been provoked...

Even more alarmingly, Alex explained to me some of the physical and verbal abuse that he faced in Croatia when he described how: 
I had bad experiences, I was attacked by some people because of the way I appear in public...my long hair...For example, my fingers were broken, my chin, I was physically, verbally and mentally abused. I don't want to mention what they said to me because I don't like those names.

When I asked Alex why he thought society was still this way after the legalization of same-sex partners in Croatia, he cited:

...the intense influence of Catholicism on society's values because they still believe in a woman and a man...relationship. Because for them...like if you want to have kids, it's only a man and a woman who can raise the kids...other things are not acceptable. From Alex's insight, it is evident how the social and religious norms in Croatia did not immediately shift with decriminalization. The legalization of same-sex relationships and identities does not directly equate freedom from persecution based on sexual and gender identity.

At the other end of the spectrum, Devin from Syria originated from a country where identifying as LGBTQ was and still is legally punishable. Devin explained how prior to the 2011 invasion by ISIS, if "you were gay, if you got arrested, you got a 1-3 year prison sentence and a one to three thousand Syrian pound fine for your first offence". After being released from prison, "you were put under supervision all of the time... and you were not allowed to get married because being gay was on your permanent government record". If you were arrested more than once, "the more rights you risked because you could not marry, you could not travel, you could not get a passport. You could not do anything." Devin expressed that although the conditions were very unstable for LGBTQ individuals while they resided in Syria, they left the country for Egypt prior to the complete takeover of the country by ISIS and the adoption of stricter Muslim norms. LGBTQ peoples who still reside in Syria today face a constant threat of violence and 
punishment for their sexual orientation. Socially, being LGBTQ is not accepted either (ILGA, 2017). Devin explained that they grew up with the expectation that men get "tough" as they get older. As a boy becomes a man, “there is always this concept of getting tough... you can't be soft. For men you get tougher when you marry and get responsibilities...when you fall into the expectations of the patriarchy...". Devin was a member of the Boy Scouts, and explained how "at one of the meetings [they] discussed what was considered sexual perversions... along with bestiality and pedophilia, men having sex with other men was considered a perversion." From these societal pressures, Devin grew up wondering what was wrong with them and used "the internet to help figure out sexuality" because they "would have lost [their] mind thinking there was something very wrong." Even though the country conditions in Syria now are very different from when Devin grew up there, the same legal, social, moral and religious norms affect the lives of LGBTQ individuals.

During my discussion with Sam, the immigration and settlement lawyer, I asked how refugee claimants' experiences differed during the asylum seeking process based on the legalities of homosexuality in their country of origin. Specifically, I questioned how the criminalization or lack thereof would influence their perceived persecution and the validity of their claim. Unexpectedly, Sam explained to me how they found that regardless of the legal ramifications of LGBTQ identities in a country of origin, "people who are genuine in their claim for persecution based on sexual orientation" are recognized because "many of the country conditions are so bad right now for so many people, and they seem to be getting worse, so in that sense they can make for very strong claims". Sam cited Jamaica as an example of this "where there is full-fledged democracy, it's completely full-functioning" and "there are not a lot of other types of claims that are coming out of Jamaica...but it's one of the worst countries for gay men.” An important 
lesson learned from Sam was that persecution based on LGBTQ identity can take many forms, and that a country does not need to legally prosecute someone for their sexual orientation in order for them to feel persecuted.

\section{Family and friends in the country of origin}

During the interviews, I asked both the refugee participants and the immigration lawyer about the role of friends and family in the asylum seekers' persecution and decision to seek protection in Canada. All three refugees expressed anxiety and hesitation over coming out to their family members and friends. For Alex from Croatia, a clear decision had been made to never tell his family members about being gay. When I questioned this notion he explained how: ...unfortunately I had to lie to my parents. The way and reason I came to Canada...they don't understand gay culture and that people are the way they are. Unfortunately this is the way it is...you know what's the word...it's a secret. I had to and continue to keep it away from them.

Alex explained how he would never tell his family about his sexual orientation and how even when he had citizenship and could travel back to Croatia, he would continue to tell his family that he moved to Canada in order to pursue a better life.

Since immigrating to Canada, Devin from Syria has been active in the LGBTQ community and is open about their sexuality on social media. When they first changed their Facebook profile picture to a rainbow in celebration of Pride 2016, their mother "got irritated" and they had a "big fight over that because she laughed and said 'you're not gay'." They did not speak for two months following this incident, and now when they speak they have developed a "don't ask don't tell" protocol. She has not mentioned or questioned their sexuality since. When I asked Devin about this alienation from their family and how their mother's unwillingness to 
accept their sexuality made them feel, they explained how they realized a long time ago that "[they] are alone and have to fend for [themselves]...in order to be true to who [they] are and come out...”. As the ultimate sacrifice of living an authentic life, Devin removed themselves from their country of origin, their family and friends, and all that was familiar in order to live an openly gay life.

Sam explained how many of their clients' feelings of persecution are founded in the attitudes of and treatment by close family and friends who become aware of their LGBTQ identity. Specifically Sam explained how "often the agent of persecution is their parents, their siblings, people that they trust, friends that they've told their sexual orientation to. So that can be very tough...". From both the immigration lawyer and the refugees, it was described how often the most intense and threatening form of persecution was instigated by the people closest to them in their country of origin. Due to social, moral and religious values alongside the varying degrees of legality, being LGBTQ was seen by family and friends as "social suicide" according to Charlie from Jamaica. Unanimously, all of the participants explained how coming out as LGBTQ did not exist in a vacuum; family members and close friends were concerned for their society's reaction to the participants and how this would influence their family name and other's perception of them. Charlie lost most of their friends because "they were afraid that associating with me would make them seem gay also", and was told by their mother that "no child from her family would ever be accepted as gay because they would be shunned by the rest of the community forever...". In short, coming out for the refugees meant alienating themselves from all of the people they were closest to during their life in their country of origin. This in turn made gaining support, whether in the form of letters of support vouching for the validity of their 
SOGIE or sending paperwork which documented persecution, from family and friends from home near impossible in many cases.

\section{Arriving in Canada}

Although all three of the refugee participants demonstrated an incredible amount of personal strength and perseverance, they unanimously cited the support of others as key to their success in Canada. Alex explained that without the assistance provided by a friend who was already residing in Canada, his immigration to Canada would not have been possible. He explained this support and how he felt after the claim started when:

...she was like you can stay at my place as long as you want...I'm going to get you a lawyer and we are going to start the process...I had a huge support from her and her husband, her sister. People that I met here, my boss. And that's it. I had an extremely amazing journey, painful at the very beginning, and just like anyone else you have ups and downs in your life, things can never be perfect. But at the same time I don't want to change a thing. The feeling when you're not isolated anymore is amazing.

Alex's friend only required that he "purchase his plane ticket over here", and then she facilitated the asylum claim, provided a room for him to stay in at her home, and helped him adjust and become financially stable until he was ready to become more independent.

During my discussion with Sam, I learned that LGBTQ asylum seekers can have access to legal counsel regardless of their financial situation. For those who cannot afford legal fees, Legal Aid Ontario covers the cost of "seven hours for the preparation of the BOC (Basis of Claim) form... and nine hours to prepare for the hearing" so that lawyers can prepare to best represent the client. At the same time, Sam reminded me that labelling someone as a refugee does not automatically mean that they are poor; many of the claimants who access their firm's 
services are affluent individuals who happen to originate from a country which does not accept LGBTQ peoples. Sam also explained that asylum seekers find the firm "through reputation, referrals from other lawyers who don't specialize in the area, service providers who offer services to the LGBTQ community, online, through a lot of other clients". Many successful claimants refer their friends from their country of origin to the firm, and Sam will often "speak to them before they even come to Canada" to determine their eligibility and the likelihood of a successful asylum claim. From these portions of the interviews, it became clear that an individual was more likely to be successful if they had support from individuals or community groups in Toronto alongside a committed and competent lawyer as soon as they arrived in Canada.

\section{Preparing for the hearing}

According to the IRB guidelines, once an asylum seeker has made a claim for Convention Refugee status, their hearing will usually take place within 60 days (IRB Claimant's Guide, 2017). All of the refugee participants and the immigration lawyer cited the pressure felt by claimants to properly prepare for their hearing. This pressure was understandable; the claimants' entire journey and the fate of their future in Canada hinged on the one-time three hour hearing with the IRB. Logistically, Sam explained how:

...if it's a standard claim we spend an hour to two hours going over what evidence they need to get together. Maybe two to four hours going over that evidence itself...making sure we've collected enough evidence to support what they're saying in their Basis of Claim (BOC) narrative. And then anywhere from three to six hours preparing for the actual hearing...including doing a mock hearing where you ask questions that the board member may ask at the hearing. 
To break down this synopsis of the hearing preparation, Sam explained how the evidence requested of the claimants can include letters of support from those who know the claimant well, police or medical records which document persecution, apartment leases or utility bills with the names of both the claimant and their partner to demonstrate cohabitation, or newspaper articles from their country of origin documenting the social or legal perception of LGBTQ individuals. As previously mentioned, gaining these documents to corroborate their claims can be much more challenging for LGBTQ asylum seekers than other categories of claimants due to their closeted identities that are often unknown to even close family members and friends.

Alex from Croatia called on a friend of his who is French Canadian, resides in Quebec, and worked with Alex overseas during the war. When he reached out to the friend he said:

... 'listen darling I need your help. We spent three years working together. You know me, everything about me. I need you for a little support. It's not a big deal. But can you write a letter of support? I need you to tell them that I spent those three years working with the government, that I am who I am. That I am gay'.

Aside from the letters of support he collected, he also had to "find a lot of information about the gay community in Croatia...to show that Croatia is not a safe place for the gay population." Alex explained that he spent hours and hours preparing for the hearing with his lawyer, talking about every detail that could help the claim and collecting all of the documents and evidence to prove his valid fear of persecution. Similarly for Charlie from Jamaica, documentation had to be compiled to demonstrate the intense persecution faced by outed LGBTQ peoples by members of society due to the complete legal and social rejection of homosexuality. Newspaper articles and records of violence towards LGBTQ individuals were included in their preparation. Although they were not able to produce letters of support from their country of origin due to the secrecy 
around their identity, they were able to get a support letter from a Toronto-based community organization stating that they participated in an LGBTQ refugee support group and volunteered their time with the community.

Although claimants' lawyers and the IRB recommend that asylum seekers present as much evidence as possible with their claim, Sam indicated that it is important to note that: ...what the law says is the presumption of truthfulness that applies to refugee hearings is that testimony alone is enough to have a claim accepted. It's not a requirement to provide hundreds of pages of documents. You don't have to.

Contrary to the dominant discourse amongst community service providers, refugees who have had successful claims, and some lawyers, a claim can be made and gain a positive result solely from the claimant's testimony which indicates that they feel persecuted. Amidst the pressure to gain a positive result from the IRB, Sam explained that a great deal of "hype" has been built around producing hundreds of pages of documents to demonstrate without a doubt that the claimant really is gay. In reality, Sam explained that "if you can support anything in your BOC narrative with a document, then why not...why not present the best claim possible?"

Both the lawyer and the refugees in my research recognized that the document collection process is a huge burden for all claimants and that it is easy to feel like they have never prepared enough or could always pull together one more piece of evidence. As explained by Charlie, it is “...easy to get caught up in the stress of preparing for the hearing...you feel like you only have one chance and you always think worst case scenario... like that you'll be deported back to your home country." When I asked Sam why they thought this was, they explained how:

...there is this odd kind of misconception that if someone is going to make a fake refugee claim then they are going to do it based on their sexual orientation. Because it's 
seen as the quote on quote 'easy way' to make a refugee claim...the kind of misconception that goes around a lot is that this is the kind of type of claim that people lie in. So I think that the sad part about that is that it puts a much higher onus on all our claimants who have a very genuine fear of persecution based on their sexual orientation. This misconception regarding LGBTQ identities being the easier to produce a fake claim was echoed by all of the refugee participants in the research. Alex explained that it feels like "nobody believes you" and that your country of origin can change the IRB's perception of you and the validity of your claim. His lawyer warned him of a previous case where another claimant from Croatia tried to prove to the IRB that he was gay even though he was heterosexual. During the hearing, he got wrapped up in the emotion and stress of the questioning and blurted out "...but what about my wife and kids? When can they come over?" His case was immediately dismissed by the IRB and he was sent back to Croatia. Alex felt even more pressure preparing for his hearing because he "...got the idea that people from Croatia are assumed to be this set of people who lie." He mitigated his anxieties over the hearing by preparing and practicing for the hearing over and over.

Sam once again pointed towards a common misconception about preparing for the hearing. Specifically from the stress over preparing for the hearing and the pressure to receive a positive result, claimants often think that they must memorize their BOC and the contents of each and every support document. Some successful claimants, service providers, and counsel insist that the formula for a successful refugee hearing is the memorization of one's story. This notion permeates throughout community organizations and former claimants, as well as in some of the literature produced as a guide for claimants. In a document entitled Hearing Preparation Kit produced by the University of Ottawa Refugee Assistance Project and funded by the Law 
Foundation of Ontario, the following statement is in bold font under the description for document collection and understanding: "Inconsistencies between your documents and your testimony could result in your claim being refused." (2016:13). Contrary to this popular belief, a claimant's story can still be interpreted as valid by the IRB even if they cannot remember the exact date and time that an incident occurred. Instead, Sam explained how:

...the BOC narrative is never crafted by me, or by other counsel. It comes from the claimants themselves...and my clients don't usually have to memorize, it's just their story. They know it better than anyone...If a client feels the need to memorize it, I often advise my clients that they maybe shouldn't put it in or maybe we should write it a different way...So we are not being like 'this happened on January 1st, 2015' and you don't know if it was the 1st or 2nd or 3rd or 4th...because when you can't remember it at the hearing, that's when issues come up.

Sam insisted that the IRB is not actually out to prove a claimant wrong and that "...counsel is always working against this misinformation...". In response to where this misinformation comes from, Sam explained how well-meaning successful claimants often:

...will have had something in their claim that worked for them and then they say 'do this in your hearing'...And that's often when people run into problems. They are going on information from people that they trust who are well-intentioned but not well-informed. Sam also recognized that this misinformation from successful claimants is a response to the stress and uncertainty of the claim and hearing; "People remember what preparing for their hearing felt like and want to provide as much comfort and support to current claimants as they can." This stress comes as a response to a process and system which has made people feel on trial for their LGBTQ identity. 


\section{The hearing}

According to both the Canadian Council for Refugees and the immigration lawyer who participated in the research, hearings by the IRB can take up to three and a half hours to complete (CCR, 2016:6). Contrary to assumptions made by claimants prior to their hearing, the hearing does not take place in a courtroom and instead resembles a board room. Typically only the board member, the refugee claimant, and the lawyer are in the room during the hearing, yet in some cases a social worker, family member or friend, interpreter, and/or witness can also be present. The format of the hearing is often at the discretion of the board member and some members are more formal than others (CCR, 2016:7). The questions asked of the claimant are also at the discretion of the board member and as explained by Sam, “...no two hearings are ever alike." The claimant's lawyer also always has the opportunity to ask the claimant questions to ensure that specific information is brought to the attention of the board member. In order to assist the claimant in their burden of proving their claim, a lawyer will often "try to establish the claimant's subjective fear, the objective basis for that fear, the ineffectiveness of protection offered in their home country, and the impossibility of an 'internal flight alternative' in their home country.” (CCR, 2016:7).

Aside from the proceedings of the hearing, Alex summarized his experience during the hearing in the following statement:

...you have to open yourself up in front of somebody you've never met. You actually have to tell them everything. From the very moment that you found yourself as a gay person, so when I was 12. And everything after that...like a timeline of your life. You tell them everything. And basically it's whatever you said to your lawyer when practicing, you have to tell them right now. I remember it. She had all my files. And she was asking 
me some of the same questions that you are asking now. You have to answer the exact same way as she has it on her pieces of paper. You have to know the how, what, where. You know, when was that, what was this. It's hard. It's exhausting, it's really exhausting. Alex's hearing took "three hours and 45 minutes" to complete and demonstrates the intense stress and anxiety felt by asylum seekers during their hearing. The hours of practicing and document collection all amount to the single appearance with the board member. As explained by Charlie, "your life path and your identity and your future fate are all in the hands of the board member sitting across from you." Alex became emotional during the hearing and said to the board member through tears: "I can't take this anymore. I'm tired of my life, I'm tired of being me. Because I can't be what I want to be'.” Even though the hearing was described as challenging and stressful by all of the refugee participants in this research, they all also cited the support and guidance from their lawyers as the key to their successful claim. Alex explained how his lawyer "worked so hard" for him, and that during "her last word to the board, surrounded with the piles of my life around her, she stated: 'my personal opinion about him is that he is a refugee claimant and deserves protection'...". That statement always stayed with Alex as it demonstrated her complete and unwavering faith in his claim and the validity of his identity.

Before going into any hearing, Sam tries to remind all of their clients that feeling the threat of persecution due to their sexual orientation and/or gender identity is enough grounds for asylum. The very feeling of threat is “on it's own under Canadian case law a form of persecution" and so even if "no one has ever been threatened, bullied, or targeted for their sexual orientation, if they've had to hide their sexual orientation, that alone is considered persecution." From this, Sam hopes to reassure their clients that they are deserving and that they can gain a positive result from their hearing as long as they speak honestly about their experiences. As 
realized by Alex, the hearing is "hard, it's really hard. But if you do believe, if you want to stay here and change your life, then be yourself and fight for yourself. The board will see that you are what you say you are...”. Overall, the research pointed to the hearing experience being stressful and emotional but necessary to their continued protection in Canada.

\section{Recommendations for future claimants}

It felt important to ask the participants in my research about any recommendations they might have for future claimants, and all of the refugee participants were eager to share what they had learned. Unanimously, all of the participants voiced that it is important for future claimants to know that the asylum seeking process is very challenging. They described the process as "much easier said than done", "not at all a walk in the park", "a fight for your life", and "quite easily the hardest thing you will ever go through". The refugees did not make these statements in an attempt to frighten or deter future claimants but instead to make sure that the realities of claiming asylum were "not sugar coated". As voiced by Alex, the process "is hard, it's very hard, and a lot of people assume it would be the easiest way to get refugee status". Similarly Charlie explained how:

...you leave everything familiar behind in hopes that strangers in a country you have never been to will understand your story and think that you are telling the truth. Sure, life at home was hard. But this is a whole other kind of hard.

All of the refugee participants expressed that it was essential to build a support network around you of successful claimants and experienced community service providers for frequent advice and encouragement.

Similarly, Sam expressed how "if you feel you have confidence in your claim and you feel you deserve protection, then it raises your confidence in being able to tell your story." All of 
the refugee participants in this research came from countries of origin which taught them that being anything other than heterosexual was wrong and unacceptable. Sam reiterated how the constant messaging that “they've done something wrong, that they've disappointed their family, and that they've gone against the grain in their culture and society" destroys their confidence and feelings of self-worth in relation to their LGBTQ identity. Sam stated how once the claimants arrive in Canada, they carry with them years upon years of feeling like who they are is wrong and what they want from their lives is a disappointment. In their country of origin they felt guilt over their LGBTQ identity, and then once they arrive in Canada "they feel bad asking or protection based on their sexual orientation." Instead, the most successful of claimants change their mindset to "understand that they deserve protection and no longer need to feel guilt or shame over their LGBTQ orientations." Charlie became more motivated and confident in their claim once they accepted that their "sexual orientation was no longer what held [them] back and instead what granted [them] the right to protection".

Sam also explained that the Canadian Bar Association has recently come out with a study which claimed that if asylum seekers "have a lawyer at a refugee hearing they have a $230 \%$ higher change of getting accepted." Simply put, accessing and working with good counsel makes a difference in the claim process. Sam and the other lawyers at their firm work on many appeal cases and see "a lot of claims that weren't done properly" and "claims that weren't successful when they should have been" because individuals either chose the wrong counsel or attempted to represent themselves during their claim. This statement was echoed by all of the refugee participants in the research who praised their lawyers and dedicated a great deal of their success to competent legal representation. 


\section{Recommendations for continued improvement of the system}

Finally for the last portion of the interviews, I asked the participants about their interpretation of and recommendations for the refugee determination system. Although there are still critiques of the system and the IRB, the release of the Guidelines for claims involving sexual orientation and gender identity on May 1, 2017 by the IRB has began to change both the refugees' and lawyer's perception of the claimant process. As stated by Sam, we are actually "in a lucky period right now because we have the sexual orientation guidelines" and they have the potential to "greatly improve the determination process for LGBTQ refugees". Sam has already noticed changes in the last few months since the guidelines were released. Further, they have noticed that newer board members at the IRB receive better training about LGBTQ claimants which produces "really good decisions on sexual orientation claims." Similarly, Alex recognized that although the experience with the IRB is challenging and stressful,

...it's the way and there are people abusing the system and the LGBTQ community by making false claims and saying they are gay. I do understand...It's the rules and regulations they have to follow...But the only thing I do know is that it is not the same for all of us. It's different. And as I said, it depends on the country you're coming from, your reasons. They're going to take a look, and if they think you belong here, they're going to let you stay. Sure the experience is hard, but this is a decision which let's you stay in the country for Christ sakes. They've got to be thorough.

Further, Sam explained how the main role of counsel is to continue to set precedent and educate board members at the IRB about sexual orientation and gender identity refugee claimants. Specifically, "there are really good resources that counsel can point to, to show that sexual orientation isn't linear. It's complex." Overall, with the continued advocacy by both lawyers and 
refugee claimants themselves, alongside the recent amendments to the IRB SOGIE guidelines (which will be discussed in further detail in Chapter 6), the IRB's interpretation of this distinct category of refugees continue to improve.

In a more critical light, both Sam and Charlie explained that a common issue faced by recent claimants is the newer timeline created by the IRB which enforces that once a claim is submitted "you have to get your hearing done within 60 days." Aside from the fact that 60 days is not a lot of time for claimants and their counsel to prepare for a hearing and collect all of the documents for their evidence, 60 days is also a tight timeline for the IRB. Sam explained that "the IRB has struggled a lot with booking hearings in that amount of time, and then they've struggled with keeping hearings on their docket...so we are having a situation right now in our office where $20-30 \%$ of our claims are going down which means they are not being heard." Although this timeline was created to reduce the amount of time claimants had to spend waiting to have their claims heard by the IRB, they have in reality created a backlog of cases which they are unable to get through fast enough. Charlie had their hearing postponed and had to wait an additional three months past their initial hearing date. For Sam, this both adversely affects the claimants by "impacting their mental health when they are already full of anxiety, making them feel like there is something wrong with their claim", and also reduces the number of clients they could have taken on if they knew they wouldn't have a hearing in the time allotted. Although postponed hearings are challenging for any category of asylum seekers, LGBTQ refugee claimants have faced some of the most prolonged and intense circumstances of waiting and hiding their identities. Due to the need for most LGBTQ claimants to remain in the closet to ensure their safety in their countries of origin, many have been waiting for years if not decades to 
gain asylum and the recognition of their SOGIE identity. Additional delays only further antagonize LGBTQ refugees and continue to persecute their identities.

As stated at the beginning of this chapter, the interview component of my research was the most rewarding and insightful. The stories and information from the participants both supported and challenged many of my preconceived notions of the LGBTQ asylum seeking process. They echoed the existing literature and provided different perspectives on the process. In the following chapter, more excerpts from the interviews will be explored and analyzed alongside an explanation of the themes found in my research and their connections to current theories and literature. 


\section{Chapter 5: A Merging of Themes - Social Actors, Waiting, and Heteronormative Systems}

In this chapter of the research, I will discuss the major themes which occurred during both the interviews and in the literature. This chapter will aim to bridge the two phenomena occurring in the LGBTQ asylum determination process in Canada; the repercussions of a deeply heteronormative and re-victimizing claimant process up against the continued education of IRB members through processes such as the recently publish Guidelines for SOGIE claimants. The refugee determination system for LGBTQ asylum seekers is currently at a turning point. This research hopes to both recognize the intense impact that the system has had on previous claimants and act as a stepping off point for further research on the lived changes felt by current and future claimants. As mentioned above, this chapter focuses on the major themes which continually arise in both the qualitative research and the published literature. The three main themes are as follows:

- LGBTQ claimants work through and against deeply heteronormative systems and understandings of sexuality;

- LGBTQ claimants face recurring long periods of waiting throughout their journey of understanding their sexuality, seeking asylum and coming to Canada, and applying for Convention refugee status; and

- LGBTQ claimants have adapted into excellent social actors who are able to perform to the specific social, political, legal, cultural, religious, etc. expectations of the environment they inhabit in order to serve their specific needs.

The rest of this chapter will explore these three themes in more detail, and the final paragraph will speculate on the effect of the changes being made to the IRB's SOGIE guidelines. 


\section{Heteronormative systems, understandings, and actions}

Many refugees, and specifically those under the LGBTQ umbrella, immigrate from countries where sexualities which differ from the heteronormative are discriminated against, completely taboo in their society, or even illegal (Bieksa, 2011:21). From this, LGBTQ refugees have been conditioned throughout their lives in their countries of origin to conceal their sexual orientation and maintain the illusion that they are heterosexual to ensure their safety and ability to participate in society. As expressed by the refugee participant from Croatia, having to live day in and day out in a "place where you know you don't belong... an extremely primitive place...a small minded place" truly takes its toll on closeted LGBTQ individuals, sometimes to the point where the individual from Croatia "refused to go out in public" and "felt a constant deep depression" while still in Croatia. Similarly, the participant from Jamaica explained how even though the country is a fully functioning democracy that attracts Westerners through its tourism industry, the "heteronormative expectations of the roles of men and women are taught from a very young age. Jamaica is not forward thinking when it comes to gays." This individual knew of another LGBTQ person who agreed to marry into a male-female relationship due to "the pressures from their family and friends" and who now "has children and has to 'play house' everyday". For many LGBTQ refugees, heteronormative standards control their lives in their countries of origin.

Once an LGBTQ refugee arrives in Canada, they may assume that they are finally free from the heteronormative expectations of their past. Although Canadian society may be more generally accepting of LGBTQ persons, the asylum determination system "entails accessing and working within a refugee system that was not designed with sexual and gender minorities in mind" (Fobear, 2014:30). After a lifetime of hiding as heterosexual, the claimant is expected in 
Canada to quickly remove their built-up shield of heteronormativity and expose their LGBTQ identity by behaving in ways which the state deems appropriate for those declaring such identities. As soon as an individual makes a claim for asylum, Katherine Fobear explains, "western constructions of sexual and gender identity are often forced upon [them]" even though "research on sexuality has shown that sexuality, sexual practices, gender, and sexual subjectivities are fluid and culturally positioned" (2014:30). Prior to the release of the most recent Guidelines, the standards of the IRB entirely enforced a Western framework of the hetero/homosexuality binary. From Gayle Rubin's pivotal Out in Theory, it is explained how the understanding of homosexuality is often determined by placing it up against heterosexuality as to be understood through its difference. Rubin explains how homosexuality is "ruled by a simplistic and homogeneous view of the psychological and social contents of the category" (2002:28). In Western society, any sexual orientation or gender identity different from the heteronormative is often framed as the key identifier of the individual who labels themselves with it, as being gay is associated with one's "primary identity and lifestyle" and the journey of "being closeted, coming out, and then being out" is the universal experience (Fobear, 2014:31).

Canadian society also has specific expectations for the expression of LGBTQ identities, and asylum seekers who have performed heteronormative identities for their entire lives do not fit the mould. In short, as goes with the title of this research, often the refugees just are "not gay enough'. This idea of the indeterminacy of the identity label of 'queer' is illustrated by David Seitz:

What makes the experience of liminality queer is twofold: First, queer here stands for the indeterminacy of identity - that which cannot be or has yet to be authenticated...in order for agents of the state to decide that they are who they say they are, that their stories add 
up, that their identities might prove essential enough to guarantee their entry into an intelligible personhood...Second, and more metaphorically, queer stands in for what structurally resists identity, what remains unintelligible or cannot be signified:

experiences of desire, precarity, and dependency that are constitutively unassimilable to the biopolitical identitarian logics governing asylum. (2016:6-7)

As is discussed later in this chapter, to work against the heteronormative understandings of sexual orientation and gender identity, LGBTQ refugees have adapted into strong social actors to meet the expectations of 'gayness' for the Canadian refugee determination system. Seitz explains, how some valid queer asylum seekers are denied their claim when they do not fit the heteronormative "nation-state litmus test of authentic gayness and thus refugeeness", citing a case with a gay man from St. Vincent (2016:9). The individual had been beaten to the point of brain damage due to homophobic persecution, yet because he "formed relationships with women and became a father to one son" he was not eligible for protection (Seitz, 9). Although such a case sounds ludicrous and rare, there have been numerous examples of denied claims where the claimant was authentically LGBTQ.

To further problematize these heteronormative standards, I turn back to Gayle Rubin who explains the "hierarchy of credibility" [...] "in any system of ranked groups, participants take it is as given that members of the highest group have the right to define the way things really are..." (Becker quoted in Rubin, 2002:27). In short, those at the top of the social systemic hierarchy are living embodiments of heteronormativity, meaning that those who are not LGBTQ hold the power to define what an LGBTQ asylum seeker really looks like as exemplified by Alex from Croatia, he laughed when I asked him how he defined his sexuality and said: 
I identify as a man who is a homosexual. Whatever you like. I don't like labels. I was never allowed to say I gay in Croatia. People in Canada are obsessed with labels. At the end of the day everything is just about love. I don't care who you are.

In summary, claimants are often assumed to be an inauthentic heterosexual under the guise of LGBTQ refugeehood until they can provide an acceptable amount of proof to match the state's understanding of what LGBTQ identities look like. As well put by Luibheid, identities “do not map neatly across time and space, and become transformed through circulation within specific, unequally situated local, regional, national, and transnational circuits" which do not correspond with "unilinear and Eurocentric models" (2008:170).

When I discussed the heteronormativity of the refugee determination system with the immigration lawyer in this research, Sam recognized that:

...there are some board members coming at assessing a claim with an obviously heteronormative mindset. You have to understand that that is the mindset of the board member. And they may not understand the intricacies of sexual orientation.

To combat this in the past, Sam has advocated that "it is the roll of counsel to educate the board member at the hearing." In response to the recently released SOGIE guidelines, Sam explained how "it makes our job easier if the board understands that not everyone is straight, and that some people don't even discover their sexual orientation until they are in their 30s and 40s, and that it's a very diverse community, and that there are complex identity issues at play." Even though there have been numerous examples of heteronormative decision-making at the IRB in the past, Sam insisted that "at baseline $95 \%$ of these board members want to make the right decision. And you have to give them the tools and advocacy to do that. The Guidelines are one of those tools." 


\section{Waiting and waiting and waiting some more}

From the above described heteronormative systems which LGBTQ refugees interact with throughout their stages of immigration, it becomes apparent how claimants would also experience long periods of waiting and indeterminacy in regards to their futures. All of the refugee participants in this research expressed how long it had taken for them to get to the place in their lives where they could sit down and openly discuss their sexuality and refugee status with me. The participants all came to understand their sexuality in their pre-teens. For Alex from Croatia, he had been watching the TV show Dynasty which featured a gay character and recognized himself in the orientation and preferences of the character. He explained how seeing the character was like a lightbulb moment "uh huh!" and that he started going to the library "to read books about sexuality". Although he was able to figure out how to categorize his sexuality, he had no option to come out and say "this is who I am." Instead, Alex stated how "unfortunately I had to wait a really fucking long time" before he could openly identify as gay. Similarly, Charlie from Jamaica expressed how they “couldn't believe it when [they] actually made it to Canada because [they] had waited for so long that [they] didn't think it would ever really happen". Devin left Syria in 2012, and waited in Egypt for three years and nine months before they were allowed to migrate to Canada. Claimants often spend a great deal of time waiting before they reach Canada (Bieska, 2011:20).

Once claimants finally arrive in Canada and seek asylum, one would expect that their wait would be over and they could settle into Canadian society. In reality, a different type of waiting and indeterminacy ensues as LGBTQ refugees begin waiting through their asylum determination process. As explained by David Seitz, the asylum determination process in Canada can be made into the metaphor of both a literal and figurative waiting room. More obviously, 
queer refugee claimants spend a great deal of time in literal waiting rooms; they wait to meet with counsel, they wait to get documents, they wait to meet with service providers, they wait at the IRB for their hearings, the list goes on. Interestingly, Seitz, influenced by Judith Butler, explains the figurative waiting room that represents:

...how waiting isn't just a temporal problem, it's an experience of liminality in the spaces of the psyche and everyday life. One doesn't simply wait in a spatial vacuum; one waits 'here', with no necessary guarantee of a hearing, much less a favourable one, and this in a constant condition of deportability. The waiting room thus flags bureaucratically induced forms of epistemic and material precarity. (2016:6)

Seitz speaks to the very real challenge faced by LGBTQ asylum seekers as they face a complete indeterminacy of their identity. They remain in limbo without status or confirmation of their queer identity, unable to plan for a future in Canada without confirmation that they are gay enough to receive protection. As was mentioned in the previous chapter, Charlie from Jamaica spent a great deal of time in the metaphorical waiting room of the asylum seeking process when their hearing was postponed for an additional three months. Although this was due to an administrative backlog at the IRB, the additional three months of waiting took an immense tole on the mental and physical health of the participant. They explained how "learning that the hearing was postponed was completely unnerving" and that they "stopped sleeping and eating well due to the anxiety". When I asked Alex to recount his years and year of waiting, he recognized that the process took an incredibly long time for him but also that he had "never felt so much freedom in [his] whole life" and that he "wouldn't change a single thing." Devin simply summarized that "the wait was worth it". 


\section{Social actors - when to hide and when to shout from the rooftops}

From an analysis of the theories of dramaturgy by Erving Goffman alongside the performance of identity by Judith Butler, the LGBTQ refugee claimant process can be described as an intense and contested 'coming out' trial which requires claimants to perform and prove their sexual orientation or gender identity. Due to the fact that sexual orientation is self-declared, often not outwardly visible, and highly variable from individual to individual, a great deal of suspicion is placed on LGBTQ claimants. While it is not unreasonable that LGBTQ refugees seeking asylum prove their SOGIE, what is suggested here is that the process goes beyond making a clear case to expecting people to live up to standards that are infused with moral codes that can be more subjective than objective. From this, the question of whether an asylum seeker is 'gay enough' to qualify for protection has been unevenly integrated into how this category of claimants seeks refuge in Canada. Proof of their sexual orientation, requested in the form of testimonies from family and community members or photos and conversations with previous same-sex partners, are all dangerously invasive. And, unlike their heterosexual counterparts, such requests are often near impossible for many claimants to produce due to the political and social climate of their countries of origin. Although the SOGIE Guidelines released for IRB board members in May of this year stand as a response to the above described problems with the LGBTQ determination process, the legacy of these practices continues to affect the experiences of current refugee claimants.

The expression of identity by an individual involves two radically different kinds of activity according to Goffman: "the expression that [they] give, and the expression that [they] give off", with the former involving the verbal communication, or "symbols", which they use to convey information and identity, and the latter involving distinct actions which are "symptomatic 
of the actor" in displaying identity (1959:120-121). From this emerges the most essential takeaway from Goffman's work, the theory of dramaturgy. According to the theory of dramaturgy, individuals go through each day as actors on the stage of life, interacting with others in patterns and scripts of pre-determined appropriate actions and speech. As defined by Goffman, a performance is the "activity of a given participant on a given occasion which serves to influence in any way any of the other participants", and the audiences are those who "contribute the other performances" to act out the "pre-established pattern of action" deemed appropriate to the situation (1959:123). Essentially, when an individual presents themselves in front of others, their "performance will tend to incorporate and exemplify the officially accredited values of the society...as an expressive rejuvenation and reaffirmation of the moral values of the community" (Goffman, 1959:125).

It is important to note that not every LGBTQ individual performs their identity in stereotypically and over-simplified 'queer' ways, even when they are in a society which would not persecute them on the grounds of their sexual orientation and gender identity; gay men do not only behave as flamboyant or obsessed with aesthetics, and lesbians do not only wear sports bras and plaid shirts and prefer male-categorized activities. Still, one has to wonder if this is a result of personal preferences, or more the fact that open and honest expressions of LGBTQ identities are calculated by individuals in accordance with the setting and audience which they are performing to. To bring a more modern theorist into the analysis, Judith Butler's theory of identity performativity both echoes and builds upon Goffman's theory of dramaturgy. LGBTQ individuals whose countries of origin persecute their orientations maintain their safety and acceptance in society through the performance of heteronormative identities. With this, any behaviour which is true to their sexual orientation, that is of homosexual encounters and 
relationships or obvious self-expression, can either be performed only in specific and secretive safe spaces, or not performed at all. In Lynne Segal's work on Judith Butler, the performativity and subjectivity of identity is beautifully illustrated through Butler's quote:

It was the 1980s, and there she sat, we learn, 'as a bar dyke', her self-description...on a stool in a gay club... 'So I was there, undergoing a cultural moment in the midst of social and political struggle...it dawned on me that some of these so-called men could do femininity much better than I ever could, ever wanted to. Ever would. And so I was confronted by what can only be called the transferability of the attribute. Femininity, which I understood never to have belonged to me anyway, was clearly belonging elsewhere, and I was happier to be the audience to it...than I ever was or would being the embodiment of it' (Butler qtd. in Segal, 2008:385).

From this personal anecdote, Butler demonstrates how identity is not only always "complex, contested, fluctuating," or subjective, but more importantly exemplifies the diversity within gender or sexual orientation and the "multiplicity of ways of displaying them" (2008:385).

As mentioned earlier in this paper, this research does not aim to challenge the authenticity of LGBTQ asylum claims. Instead, I recognize the validity of this category of claims and call for the continued recognition of LGBTQ refugees in Canada. Building from the theories of Goffman and Butler, I aim to show how although LGBTQ refugees may originate from countries with strict heteronormative understandings of sexuality, they have adapted during their immense time spent waiting to be able to perform to the standards of the LGBTQ asylum determination criteria in Canada. These claimants are not new to social performativity; from the time in their countries of origin when they realized they were queer, they learned how to perform to meet the heteronormative standards of the society around them. As is demonstrated in the 
following quote by Devin from Syria, a clear segregation of people and spaces in their life allowed for appropriate social performances which kept them safe while they were still in Syria: As soon as I connected the dots and realized I was gay, I immediately started readjusting myself to be hidden in the closet. I separated everything in my life. My friends from school didn't know my friends from work. They didn't know anyone at the university. The university didn't know anyone in my family. And, of course, my family didn't know anyone from my surrogate family...being known as gay was containable. I had control and could behave in certain ways to certain groups in my life.

Devin took on a multi-faceted identity which, in echoing Goffman, allowed them to behave in certain ways deemed appropriate to the certain groups around them. For the most part, Devin lived a strictly closeted life, but they were able to build a 'surrogate family' of close friends who they could trust their identity with and be openly gay to. This group allowed for Devin to participate in an "after hours" life at night where they could "go meet friends, not take [their] ID, and say [their] name was Greg. [They] would have parties in houses where [they] were able to be whatever and whoever...it was safe... and it's how [they] survived."

Once the claimants arrived in Canada, they sought out assistance and advice from service providers, counsel, and other LGBTQ refugee claimants. Through observation of and interaction with these groups and getting a sense of Canadian norms, they were able to glean what the heteronormative understandings of SOGIEs were to ensure that their claim met the demands of the IRB's expectations as determined by the individual board members. This is not to say that the claimants were dishonest on their Basis of Claim forms or produced false evidence of their LGBTQ identity; the claimants adapted to perform the aspects of their identity which were crucial to the success of their claim. This is most clearly demonstrated by Charlie from Jamaica 
who included in their claim newspaper articles about LGBTQ persecution in Jamaica, a letter of support from a close friend from Jamaica who knew of their sexual orientation, "some fairly dirty Facebook messages between a [person] I had been seeing, and a confident and honest telling of the legitimate fear I had of returning to Jamaica." Charlie explained how they “wouldn't usually speak so openly and honestly about [their] sexuality because it was never cool to talk like that back home" but they realized that the stereotypically homosexual performance of their identity would ensure a successful hearing result. Similarly, Alex summarized to the board member how he was really good at "social camouflage" but when asked about same-sex relationships answered:

‘...excuse me - I can't say the person's name - I don't want to, um, upset someone else's privacy. But before him I never had a boyfriend. I'd never been in a relationship and stuff like that. I hadn't been, excuse me, he was the first man I ever met. And that's it.' They then have to ask you a lot of personal questions. Your sexual experiences. And I'm like 'ok you really want to know? Well excuse me, physically I'm a virgin but mentally I'm a whore. Just like a porn star.' That seemed to convince them.

Although Alex's quote is comical to read, the sentiment demonstrates how LGBTQ asylum seekers have learned to best perform their gayness to the IRB to ensure protection and survival. When I asked Sam about the need for claimants to best perform their SOGIE to the IRB, they recognized the difficulties in proving sexual orientation. They explained how "it's a myriad of issues. There are so many different ways to prove it. And there isn't just one kind of smoking gun in these cases that, you know, that says yes you're gay." Instead, Sam once again called back to the fact that even in situations where claimants have not been physically attacked, the very threat of any form of persecution due to their SOGIE is grounds for asylum in Canada. 
Ultimately, Sam cited "an honest, confident, and direct hearing" as the best way to ensure a positive outcome.

\section{The future of the LGBTQ asylum determination process}

Although this chapter points to the many issues that LGBTQ refugee claimants have faced during interactions with the IRB, it is also crucial that this research highlights the step which has been taken with the release of the SOGIE Guidelines for board members. Sam recognized how:

...there is a small minority [of board members] that are still left over from the time period that a refugee was expected to be a lot more descriptive and exact... when they would do what we call a microscopic review, which means they went though the claim with a fine toothed comb and every single possible issued was raised and every specific and personal question was asked.

Regardless, this research hopes to act as a stepping off point to tracking the direct and lived impact of the SOGIE Guidelines on LGBTQ asylum seekers. The last chapter of this research will analyze the Guidelines and highlight some of its most important components. 


\section{Chapter 6: A Changing System: The IRB's SOGIE Guidelines}

As discussed throughout the research, 2017 has been an important year for reforms at the IRB to improve the processes around refugee claims based on sexual orientation and gender identity persecution. As was demonstrated in the findings from the research interviews, and put so well by the LGBTQ refugee lawyer interviewed, "now is the time to start tracking the changes in refugee claims based on sexual orientation...I think it's just sometimes the machine moves slowly...but a more balanced approach to the types of decisions holds a lot more credibility." During this period of multiple amendments and improvements to a system which still faces the ramifications of past processes, this last chapter works to be a starting-off point as the IRB and the individuals who work for, through and with the LGBTQ refugee claim system enter into a new period of reform and possibility.

On May 1, 2017, the Immigration and Refugee Board of Canada (IRB) released the most recent update to the refugee boards' Chairperson's Guidelines entitled Proceedings Before the IRB Involving Sexual Orientation and Gender Identity and Expression. The development of these guidelines specific to LGBTQ refugee claimants are in large part due to the advocacy of the late Professor Nicole LaViolette from the Faculty of Law at the University of Ottawa (IRB, 2017). According to Sam,

Professor LaViolette used to do the training at the IRB on these types of claims. And she had been pushing for there to be guidelines on sexual orientation claims for almost a decade. So it had been in the works from my understanding, from the policy end of things at the IRB, for quite a while.

In the introduction of the guide published on the IRB's website, it is explained that the document "addresses the particular challenges individuals with diverse SOGIE may face in presenting their 
cases... and establishes guiding principles for decision-makers in adjudicating cases involving SOGIE" (2016:2). The guide provides definitions for a wide range of LGBTQ terminologies including but not limited to gay, gender, sex, gender expression, pansexual, trans, intersex, queer, and cisgender. Most importantly, in section 1.4, the guide explains how it has been developed to fill the knowledge gap of IRB personnel who are involved in the processing or adjudication of LGBTQ cases on the following themes:

i. Understanding the unique challenges faced by individuals with diverse SOGIE in presenting evidence pertaining to SOGIE;

ii. Using appropriate terminology and language in both proceedings and reasons for decision when referring to individuals with diverse SOGIE;

iii. Protecting sensitive information in reasons for decision;

iv. Avoiding stereotyping and inappropriate assumptions when making findings of fact;

v. Assessing credibility; and

vi. Increasing awareness of circumstances unique to individuals with diverse SOGIE that may affect findings of fact and findings of mixed fact and law in each of the four divisions.

The development and publishing of these Guidelines is an incredibly important step for the recognition of and improvements for such a specific and marginalized group of refugees. Prior to the release of the Guidelines, as highlighted in the previous chapters, the IRB was intensely criticized by academia, the media, claimants, and counsel to name a few for their treatment of LGBTQ refugee cases. As explained in Chapter 3, the only direction for IRB board members in regards to LGBTQ asylum seekers was under Guideline 8 which provided special support for individuals identified as Vulnerable Persons. Under the definition of vulnerable 
persons, "those disadvantaged due to their sexual orientation or gender identity" were included to allow board members to "consider how membership in a vulnerable group affects a person's ability to provide evidence and testimony" (Egale, 2017). As expressed by Sam,

LGBTQ rights abroad are kind of the last area where there is still so much work to be done... and immigration law is at a stage where we are literally crafting the laws that are happening right now. So it's a very exciting time to be practicing in this area.

When reading through the guide, it is clear that refugee claimants and counsel were consulted for the development of the Guidelines. Sam explained how although the Guidelines took quite a while to be developed and released, the IRB did "ask for feedback from counsel" during the summer of 2016 and amendments were made based on the suggestions from various service providers. In considering what Guidelines are most relevant to this research, Section 3.2 points to the fact that an individual testimony "may be the only evidence of their SOGIE where, in a given case, corroborative or additional evidence is not reasonably available" (IRB, 2017). This reality was echoed by both the immigration lawyer and the refugee participants in the research in Chapter 4. Further, the Guideline's Section 6.1 offers an inclusive approach to a typically heteronormative interpretation of LGBTQ identities. Specifically, the guide suggests to decision-makers that they "should not rely on stereotypes or inappropriate assumptions... as they derogate from the essential human dignity of an individual" (IRB, 2017). This move away from identity stereotyping represents one of the greatest achievements of the Guidelines as it puts into practice the fact that LGBTQ identities from various cultures and countries of origin do not exist in a vacuum. Instead, it recognizes that the common Western understandings of LGBTQ-ness do not apply to any and all people on the spectrum. The guide provides examples of some of the common stereotypes which have been employed by both IRB board members and 
heteronormative society as a whole in the past, and I feel as though these new standards are crucial to the continued development and improvement of the LGBTQ refugee determination system. The list has been included in full in this research in hopes to continue the dialogue and tracking of progress as these guidelines are enacted by the IRB. The list of stereotypes is as follows under Section 6.1:

- Individuals with diverse SOGIE have feminized or masculinized appearances or mannerisms;

- Individuals with diverse SOGIE do not participate in cultural or religious customs or traditions;

- Romantic or sexual relationships share the same dynamics and characteristics across cultures;

- An individual knew they were an individual with diverse SOGIE at a young age, or became sexually active at a young age;

- Trans individuals will seek to have surgical or physiological treatment if they have access to that treatment;

- Individuals with diverse SOGIE are promiscuous or sexually active and do not engage in exclusive relationships;

- Individuals with diverse SOGIE have had same-sex sexual experiences or relations;

- Individuals with diverse SOGIE would not have had heterosexual sexual experiences or relations;

- Individuals with diverse SOGIE would not voluntarily enter a heterosexual marriage or have children;

- An individual's SOGIE can be determined by an individual's occupation; and 
- Individuals with diverse SOGIE would actively participate in LGBTIQ+ culture in Canada, including frequenting LGBTIQ+ predominant areas and social establishments, or be involved in community organizations and groups.

It is important to note once more that the refugee participants interviewed for this research all went through the refugee hearings prior to the release of these IRB Guidelines. Although the participants had fairly positive experiences during their hearing with board members, some of the above listed stereotypes still emerged during the members' questioning. As explained by Sam, in the past:

there were a lot of issues around how board members decided on claims...you'll see even in the federal court cases where a board member asked for intimate sexual details from a client. And repeatedly, federal court cases came out saying you can't ask people that, it's insensitive, it's invasive. And it doesn't mean that they aren't a sexual minority because they haven't slept with somebody of the same sex. So you'll notice from the federal court, and they are often dated because they were in the early 2000s, when a lot more of that type of questioning was happening.

With this, my research aims to continue to document this slow change over the past ten years and how it further improves the conditions for LGBTQ asylum seekers.

This chapter has been included in the research not only to encourage further research about the impact of the IRB's new Guidelines, but also to act as an addendum to the reader's understanding of the narratives expressed by both the refugee participants and the immigration lawyer. All of the refugee participants interacted with the system prior to these monumental changes, and the immigration lawyer has worked with claimants prior to, during consultation for, and after the release of the Guidelines. I do not wish to imply that Sam is the sole expert voice on 
the IRB SOGIE Guidelines. Instead, Sam's many years of experience provides immense insight into the Guideline's potential. Other immigration lawyers should be interviewed in the future as these changes continue to evolve at the IRB. It is also important to note that the new IRB Guidelines do not make for overnight change for LGBTQ refugee claimants. History shows us that systems continue to support and maintain heteronormative understandings of the world. Future research questions could include: Will the Guidelines break down heteronormative understandings of homosexuality? Will refugee claimants ever feel as though the claimant process is less of a 'coming out' trial which assumes they are straight until proven gay? Will the IRB adjust its administrative functions to decrease wait times for individuals already in limbo? And will LGBTQ asylum seekers continue to feel the need to demonstrate their SOGIE through stereotypical and overt performances? Future research will have to tell. 


\section{Chapter 7: Conclusion}

My research was founded in the discourse created and reproduced by the current literature surrounding LGBTQ refugees in Canada. I had assumed that the participants in my research would support my hypotheses that the IRB refugee determination system is inherently unfair to LGBTQ claimants, and that it demands queer refugees disclose a great deal of intimate personal information to meet heteronormative markers of gayness. Although these experiences still occur for queer asylum seekers today, the participants in my research pointed towards a shift in the IRB claim process. Overall, the participants recognized that the system is made and maintained by those who view the world through a heteronormative lens. They also all indicated their struggles with lengthy bureaucratic processes which made an already stressful experience that much more difficult. Ultimately, my research pointed towards the fact that claimants have adapted to meet the expectations of the IRB's LGBTQ refugee determination system. Through the sharing of information amongst fellow claimants, service providers, and legal counsel, queer refugees have become outstanding social actors who have learned how to perform their queerness to gain a positive IRB result that ensures their protection from their countries of origin. It is important to note that this does not mean that anyone who wishes to seek asylum in Canada can do so under the guise of LGBTQ identities. Instead, this category of refugees has always been and will remain valid, and claimants have learned to perform the aspects of their identity which meet the stereotypical demands of the IRB and other heteronormative Canadian systems.

As was discussed in Chapter 6 of this MRP, seemingly positive changes are currently underway at the IRB which have the potential to alter the treatment of LGBTQ asylum seekers. The new SOGIE Guidelines for IRB members released in May of 2017 represent the recognition of the unfair and unrealistic demands made of queer refugees in the past. The Guidelines call for 
a shift in thinking and interpreting by board members; heteronormative stereotypes and behavioural indicators can no longer stand as the markers of if someone is queer enough or not to deserve protection based on SOGIE identities. From this, my research ends with a call to action for future investigators: will the shift in discourse at the IRB alongside the continued dialogue by refugees, service providers, legal counsel, the media, and academics change the perception and treatment of LGBTQ refugee claimants? I ask that future researchers in this field dedicate themselves to tracking the changes, whether positive or negative, which follow the Guidelines.

Ultimately, my research was motivated by social justice. After studying immigration and settlement and focusing on the specific treatment of LGBTQ refugees, I knew that more research was needed to provide a platform for these marginalized voices and to call for continued improvements to the system. The new Guidelines are only a stepping-off point for hopefully many more reforms to come. To end my research, I wanted to bring back the voice of a refugee participant. Although I was telling a story in this research, my main objective was always to act as a vehicle for telling the stories of SOGIE refugees. Alex from Croatia summarized and provided advice for the asylum-seeking process so well in the following quote:

Welcome to Canada, the land of freedom, and Justin Trudeau, and gays. But no, to be serious, you have to prepare yourself. You have to be mentally ready. The procedure isn't easy. You have to work really hard, you have to fight for it. And even if they decide that you can stay, don't think that it's going to be honey and roses and stuff like that. Find work, get a good job. And get ready to have your ego knocked down. But remember that it is all worth it. So never stop fighting. 
To former, current, and prospective LGBTQ refugee claimants:

Your SOGIE identity is valid. Your experiences which led you to seeking asylum are important. You are welcome and belong in Canada. And you are gay enough. 


\section{Appendices}

\section{A: Recruitment letter}

To whom it may concern:

Thank you for your interest in the following research project being conducted by Allison Holder, Master of Arts in Immigration and Settlement Studies student candidate, at Ryerson University:

\section{You're Not Gay Enough: The Experiences and Challenges of LGBTQ Refugees During the Asylum Determination Process in Toronto}

This connection is being made between you and the researcher because you fall under the criteria for the research and you may be interested in participating. The description below will provide you with more information about the process and aims of the research.

This research will aim to understand the experiences of Lesbian, Gay, Bisexual, Transgender, and/or Queer (LGBTQ) asylum-seekers' interactions with refugee claim processes and policies in Canada, specifically focusing on the individual experience of refugee claimants in Toronto. The research will seek out 4-6 participants who have fully completed the refugee determination process and have been granted Convention Refugee status from the Immigration and Refugee Board (IRB). The participants will be required to prove that they are at least 18 years of age, to demonstrate that they can converse in and comprehend English, and attend a one-time in-person interview with the researcher, Allison Holder, not exceeding one and a half hours, on the Ryerson University campus at the Student Learning Centre at 341 Yonge St.

The research will not include anyone who is planning on making a refugee claim, is in the process of making a refugee claim, or has been denied their refugee claim on the grounds of LGBTQ identity. Through interviews with participants, the research will aim to show the realities of the asylum hearing process, demonstrating how claimants are required to prove their LGBTQ identity. This research is being completed by Allison Holder as a required component of the Master of Arts in Immigration and Settlement Studies program. The research information gathered will be put into a written Major Research Paper. This study has been reviewed and approved by the Ryerson University Research Ethics Board.

Further research is needed to help better understand and support the needs of this very specific, marginalized, and vulnerable group which has already experienced a great deal of trauma in their countries of origin. The research acts as both a way for the participants to open-up about their refugee claim experiences, expressing the challenges and needs they felt during the process, and as a way for future claimants to be better supported and treated during future hearings. There is also the potential that this research could contribute to changes in the Immigration and Refugee Board hearing procedures in the future. 
If you are interested in participating in this research or have any questions about it, you can contact the researcher at allison.holder@ ryerson.ca or 705-394-4581 for more information.

Sincerely,

Allison Holder

\section{B: Consent form}

\section{Ryerson University Consent Agreement}

You are being invited to participate in a research study. Please read this consent form so that you understand what your participation will involve. Before you consent to participate, please ask any questions to be sure you understand what your participation will involve.

\section{RESEARCH TITLE:}

You're Not Gay Enough: The Experiences and Challenges of LGBTQ Refugees During the Asylum Determination Process in Toronto

\section{INVESTIGATORS:}

This research study is being conducted by Allison Holder, Master of Arts in Immigration and Settlement Studies student candidate at Ryerson University. This research is being supervised by Dr. Doreen Fumia from the Department of Sociology at Ryerson University.

This study is not funded.

If you have any questions or concerns about the research, please feel free to contact Allison Holder at allison.holder@ryerson.ca.

\section{PURPOSE OF THE STUDY:}

The research will aim to understand the experiences of Lesbian, Gay, Bisexual, Transgender, and/or Queer (LGBTQ) asylum-seekers' interactions with refugee claim processes and policies in Canada, specifically focusing on the individual experience of refugee claimants in Toronto. The research will seek out 4-6 participants who have either fully completed the refugee determination process and have been granted Convention Refugee status from the Immigration and Refugee Board (IRB), or who have been directly involved in the support and/or counsel of LGBTQ refugee claimants. Through interviews with participants, the research will aim to show the realities of the asylum hearing process, demonstrating how claimants are required to prove their LGBTQ identity. This research is being completed by Allison Holder as a required component of the Master of Arts in Immigration and Settlement Studies program. The research information gathered will be put into a written Major Research Paper.

\section{WHAT YOU WILL BE ASKED TO DO:}


If you volunteer to participate in this study, you will be asked to do the following things:

-provide proof that you are at least 18 years of age and have either been granted legal Convention Refugee status in Canada, or are directly involved in the support and/or counsel of LGBTQ refugee claimants -demonstrate that you can converse confidently in English to ensure understanding of the interview questions and consent forms/criteria -review this consent form prior to participation in the study -attend a one-time in-person interview with the researcher, Allison Holder, not exceeding one and a half hours, either on the Ryerson University campus at the Student Learning Centre at 341 Yonge St. or at a location of your convenience -answer questions regarding, including but not limited to, LGBTQ refugee identities, circumstances in various countries of origin, refugee claim experiences, hearings with the Immigration and Refugee Board, and your reflections on the Canadian immigration system -consent to an audio recording of the interview and notes made by the researcher

Sample research questions include:

For what reasons do LGBTQ refugee claimants flee their countries of origin?

Do LGBTQ refugee claimants have enough supports prior to, during, and after their hearing?

Following the completion of the interviews, audio recordings and research notes can be made available to you at your request. These files will be provided to you through email if requested. Following the completion of the researcher's Major Research Paper, you will be sent an electronic copy of the report.

\section{POTENTIAL BENEFITS:}

There are potential benefits for both the individual participants of the research and the LGBTQ refugee community as a whole. Further research is needed to help better understand and support the needs of this very specific, marginalized, and vulnerable group which has already experienced a great deal of trauma in their countries of origin. The research acts as both a way for you to open-up about the refugee claim experience, expressing the challenges and needs you felt during the process, and as a way for future claimants to be better supported and treated during future hearings. There is also the potential that this research may form the basis of future research and could contribute to future policy decisions.

I cannot guarantee, however, that you will receive any direct personal benefits from participating in this study.

\section{WHAT ARE THE POTENTIAL RISKS TO YOU AS A PARTICIPANT:}

The potential risks to you in this study are very low. I will be asking you about your personal experiences with the LGBTQ asylum process, and discussing situations of persecution and trauma. All of these topics could trigger you and make you feel anxious, upset, uncomfortable, angry, and in the worst case, cause re-traumatization. Although I will work to remove any and all individual identifiers from the research findings, the LGBTQ community and those who provide services and counsel to the community, are quite small in Toronto. Many of the individuals I am interviewing will know the other research participants or service providers, and certain stories or 
descriptions of circumstances could be tied back to you or the other research participants. It is crucial to note that although every effort will be taken to maintain the complete anonymity of you and the other participants in the research, there is still the potential that readers of the final report could glean who the research findings and quotes are about. Your awareness of and consent to this potential recognition is mandatory for involvement in the research.

I will ask you prior to the beginning of the interview if any discussion topics are off-limits or outside of your comfort zone. Also, I will remind you that you can decline to comment or answer questions at anytime during the interview if the subject matter is too personal or triggering. Further, I will be removing all factors which I think could cause you to be identified, including but not limited to your appearance, school program, place of work, location you inhabit in the city, interaction with specific organizations, etc.

\section{CONFIDENTIALITY:}

The participants in the research will be known to me, Allison Holder, as the researcher due to the in-person interview style of information collection. To ensure your confidentiality, I will remove all defining characteristics from the data, specifically your name and recognizable personal circumstances, so that you and the other individuals will not be recognized from the research. I will store all contact information, notes, and recorded interviews with you in separate password encrypted documents and locked filing cabinets.

The audio recordings of the interview will not be played for anyone but the researcher, Allison Holder, and the sole purpose of the audio recordings is to allow the researcher to transcribe comments and answers from you and the other participants following the interviews.

I will keep the data for one year following the completion of the Major Research Paper to ensure that any questions or concerns in relation to my findings can be properly answered and referenced. I will keep the data for this period of time in case you wish to access the data following the completion of the project. After a year has passed, I will delete all of the files from my computer which contain research data, recorded interviews, and the contact information of you and the other participants. I will delete any emails or messages between us which include research and personal information. I will also shred all interviews notes, transcripts, and rough drafts of the major research paper. I will hold onto electronic scans of the consent forms for one year following the research to ensure I have proof of your consent due to the personal nature of the interview content.

\section{INCENTIVES FOR PARTICIPATION:}

As a thank you for your participation in this study, if you desire, I will purchase for you a beverage and snack of your choice prior to the interview. This will be limited to six people, my maximum number of research participants.

\section{COSTS TO PARTICIPATION:}

If you desire, I will provide you with two public transit tokens to reimburse you for the travel expenses to and from the in-person interview. The tokens will be provided to you immediately following your interview. 


\section{VOLUNTARY PARTICIPATION AND WITHDRAWAL:}

Participation in this study is completely voluntary. You can choose whether to be in this study or not. If any question makes you uncomfortable, you can skip that question. You may take a break during the interview, reschedule the interview, or stop participating at any time during the interview. If you choose to stop participating following the interview, you may also choose to not have any of your data included in the study up until August 1st, 2017. This deadline is the ensure the researcher can complete the project on time. For one week following the interview, you may also contact the researcher and request that specific content be removed from your interview transcript. Your choice of whether or not to participate will not influence your future relations with Ryerson University, the department of Immigration and Settlement Studies, or the investigator, Allison Holder, involved in the research.

\section{QUESTIONS ABOUT THE STUDY:}

If you have any questions about the research now, please ask. If you have questions later about the research, you may contact:

Allison Holder

MA of Immigration and Settlement Studies student candidate

Ryerson University

allison.holder@ryerson.ca

705-394-4581

OR

Dr. Doreen Fumia

Department of Sociology

Ryerson University

dfumia@ryerson.ca

416-979-5000 ext. 2605

This study has been reviewed and approved by the Ryerson University Research Ethics Board. If you have questions regarding your rights as a participant in this study please contact:

Research Ethics Board

c/o Office of the Vice President, Research and Innovation

Ryerson University

350 Victoria Street

Toronto, ON M5B 2K3

416-979-5042

rebchair@ryerson.ca

\section{RESEARCH TITLE:}

You're Not Gay Enough: The Experiences and Challenges of LGBTQ Refugees During the Asylum Determination Process in Toronto

\section{CONFIRMATION OF AGREEMENT:}


Your signature below indicates that you have read the information in this agreement and have had a chance to ask any questions you have about the study. Your signature also indicates that you agree to participate in the study and have been told that you can change your mind and withdraw your consent to participate at any time within the indicated timelines. You have been given a copy of this agreement.

You have been told that by signing this consent agreement you are not giving up any of your legal rights.

Name of Participant (please print)

Signature of Participant

Date

I agree to be audio-recorded for the purposes of this study. I understand how these recordings will be stored and destroyed.

Signature of Participant

Date

\section{C: Interview guides}

\section{Guide for Convention Refugees}

For my records only, what is your name and age? As a reminder, this information will in no way be tied to your following answers. All findings presented in my Major Research Paper will be anonymous.

What is your country of origin? What is your current immigration status?

Where do you identify on the LGBTQ spectrum? What does this identity mean to you?

How old were you when you first realized that you did not align with heteronormative understandings of sexual orientation and gender identity?

What is your country of origin's policy in regards to identifying as LGBTQ? Is it socially, politically, and/or legally punishable?

Could you openly identify as LGBTQ in your country of origin? Is there a LGBTQ community?

Does your family know that you identify as LGBTQ? If yes, when did they find out? If no, why do they not know? 
Does your family support your LGBTQ identity? Are they here with you in Canada or do they remain in your country of origin? Do you have contact with them?

Were you in a LGBTQ relationship prior to migrating to Canada? If so, could you be publicly open about this relationship in your country of origin?

What persecution did you face in your country of origin due to your sexual orientation and/or gender identity?

When did you first arrive in Canada?

Why did you decide to migrate and seek refuge in Canada?

When you arrived, were there resources immediately made available to you? Did you have access to settlement workers and immigration lawyers?

What were your first few months in Canada like?

Have you felt supported as a LGBTQ refugee in Canada?

Where did you find information and access to housing, employment, government-issued IDs, education, health care, mental health services, public transit, social assistance, etc.?

What worked well during your claim? Where did you get your support and guidance from?

What didn't work well during your claim? How could you have been better supported?

What was your IRB hearing experience like? Did you have to provide proof of your LGBTQ identity? If yes, how did the IRB ask you to demonstrate this?

Did you feel like you were believed by the government, community organizations, fellow refugees, your lawyer, and/or the IRB you when you made your refugee claim based on LGBTQ identity? (you can answer individually for each of these categories)

Do you think the IRB hearing process should be changed for LGBTQ refugees in the future? If yes, how should it be changed?

Do you know of any LGBTQ refugees who have had their claims denied?

How has your experience as a refugee in Canada adhered to or varied from your expectations?

Are there services and community organizations which provide you with the support that you needed following the successful completion of your claim?

Do you feel as though you are a member of Canadian society? Do you feel more accepted here than in your country of origin? 
Are you now comfortable with openly expressing your LGBTQ identity?

Have you been able to secure employment and/or educational opportunities in Canada? Was it challenging to do so?

What are your next steps for your life in Canada?

If you could provide any words of encouragement, advice, or support for future LGBTQ claimants, what would you say?

\section{Guide for service providers}

What is your background? What motivated you to become an immigration lawyer?

How long have you been representing LGBTQ refugees?

Can you tell me a little about the process? How does a claimant find you? Is there legal aid available to them? What are the wait times like to find a lawyer? Do individuals with money have a better chance of finding representation?

How long does it take to prepare for an IRB hearing? What kinds of information do you collect to prepare? How do you best prepare your client?

What is the hardest part about getting client's ready for their hearing? Is there any information that they must provide that you think is unfair or too much?

How do LGBTQ refugee claimants differ from other categories of refugees (i.e.: economic, war)

Have you noticed any particular countries of origin which produce higher numbers of LGBTQ refugees? If yes, do you know why?

What are the typical experiences of persecution faced by LGBTQ refugee claimants?

Is it harder for a LGBTQ claimant to accumulate evidence for their hearing? What kinds of proof are they required to present?

Does it feel like going into the hearing that you and the claimant have to prove the legitimacy of their gayness?

Have you noticed any tactics that the claimants use to help them prove their stories and gain a positive outcome from the IRB?

From my research and interviews with successful LGBTQ refugee claimants, I have noticed three main themes. These are that the claimants are adaptable social actors, that they all 
experience long periods of waiting, and that the current Canadian legal system which determines their fate is incredibly heteronormative. Can you comment on any of these findings?

Is there a particular case of a LGBTQ refugee that stands out to you? If yes, why is it memorable? What was their story?

Have you ever had clients whose claims were denied?

Are you aware of any cases were individuals lied and claimed they were LGBTQ in order to seek asylum in Canada?

Do you think the hearing process is sound? Is it the best way for Convention refugee status to be determined? How else could the process work?

If you had any advice for future LGBTQ claimants, what would it be?

\section{Bibliography}


Bain, A., Payne, W., and Isen, J. (2015). Rendering a neighbourhood queer. Social and Cultural Geography, 424-443. Retrieved from http://dx.doi.org/10.1080/14649365.2014.991750

Berg, L., and Millbank, J. (2007). Constructing the Personal Narratives of Lesbian, Gay and Bisexual Asylum Claimants. Journal of Refugee Studies. Vol. 22 (2), 195-223.

Berg, L., and Millbank, J. (2013). Developing a Jurisprudence of Transgender Particular Social Group. In Thomas Spijkerboer(ed) Fleeing Homophobia, Routledge. 121-153.

Bieksa, L. (2011). The refugee qualification problems in LGBT asylum cases. Mykolas Roomers University, Faculty of Law and Department of International and European Union Law. Retrieved from https://www.mruni.eu/upload/iblock/7fb/15_Bieksa.pdf

Browne, K. (2007). Introduction: towards trans geographies. Gender, Place \& Culture: A Journal of Feminist Geography. 5(17), 573-577.

Carroll, A. \& Itaborahy, L. (2016). State-Sponsored Homophobia: A World Survey of Laws, Criminalization, Protection and Recognition of Same-Sex Love. International Lesbian, Gay, Bisexual, Trans and Intersex Association. Retrieved from http://old.ilga.org/Statehomophobia/ILGA_State_Sponsored_Homophobia_2015.pdf

Canada Research Team. (2015). Canada Research Team: Envisioning LGBT Refugee Rights in Canada. Social Sciences and Humanities Research Council of Canada \& York University. Retrieved from http://envisioninglgbt.blogspot.ca/p/publicationsresources.html

Canadian Council for Refugees. (2016). IRB Hearings Report. Retrieved from http://ccrweb.ca/files/irb_hearings_report_final.pdf

Canadian Council for Refugees. (2017). Hearing Preparation Kit for Refugee Claimants. Retrieved from http://ccrweb.ca/files/hearing_preparation_kit.pdf

CBC News. (2015). Timeline: Same-sex rights in Canada. Retrieved from http://www.cbc.ca/news/canada/timeline-same-sex-rights-in-canada-1.1147516

Code, L. (1993). In Alcoff, L. and Potter, E. Feminist Epistemologies. Routledge, New York, 1548. Retrieved from https://books.google.ca/books?id=zT20AAAAQBAJ\&lpg=PR3\&ots=D74zsiOUtR\&dq= code $\% 20 \mathrm{in} \% 20$ alcoff $\% 20$ and $\% 20$ potter $\& \operatorname{lr} \& p g=P R 5 \# v=$ onepage $\& q=$ code $\% 20 \mathrm{in} \% 20$ alc off $\% 20$ and $\% 20$ potter $\& \mathrm{f}=$ false

Corbin, J. and Strauss, A. (2008). Basics of Qualitative Research: Techniques and Procedures for Developing Grounded Theory. Sage Publications, Los Angeles.

Egale. (2017). FAQ: LGBT issues in Canada's Immigration and Refugee System. Retrieved 
from https://egale.ca/faq-immigration/

Fobear, K. (2014) Queer Settlers: Questioning Settler Colonialism in LGBT Asylum Processes in Canada. Refuge: Canada's Journal on Refugees, Vol. 30 (1).

Goffman, E. (1959) Chapter 9: The Presentation of Self in Everyday Life, Selections. In Sociology Exploring the Architecture of Everyday Life Readings, edited by Newman, D. \& O'Brien, J. (120-127)

Government of Canada. (2017). Claim refugee protection. Retrieved from http://www.cic.gc.ca/english/refugees/inside/index.asp

Hartstock, N. (1998). The feminist standpoint revisited and other essays. Westview Press. DOI: https://philpapers.org/go.pl?id=HARTFS\&proxyId=\&u=http\%3A\%2F\%2Fdx.doi.org\%2 F10.1353\%2Fhyp.2002.0033

Hojem, P. (2009). Fleeing for love: asylum seekers and sexual orientation in Scandinavia. The UN Refugee Agency Policy Development and Evaluation Service, No. 181. Retrieved from http://www.unhcr.org/4b18e2f19.pdf

ILGA. (2017). Maps: Sexual orientation laws. Retrieved from http://ilga.org/what-we-do/mapssexual-orientation-laws/

IRB. (2016). Refugee Claimant Demographics. Retrieved from http://www.irbcisr.gc.ca/Eng/RefClaDem/Pages/ClaDemGuide.aspx

IRB. (2017). Refugee Claimant Guide. Retrieved from http://www.irbcisr.gc.ca/Eng/BoaCom/references/pol/GuiDir/Pages/GuideDir09.aspx\#a1

IRB. (2017). Chairperson's Guideline 9: Proceedings Before the IRB Involving Sexual Orientation and Gender Identity and Expression. Retrieved from http://www.irbcisr.gc.ca/Eng/BoaCom/references/pol/GuiDir/Pages/GuideDir09.aspx

IRB. (2006). Chairperson Guideline 8: Procedures With Respect to Vulnerable Persons Appearing Before the IRB. Retrieved from http://www.irbcisr.gc.ca/Eng/BoaCom/references/pol/GuiDir/Pages/GuideDir08.aspx

LaViolette, N. (2013). Overcoming Problems with Sexual Minority Refugee Claims: is LGBT Cultural Competency Training the Solution? Fleeing Homophobia, University of Ottawa.

LaViolette, N. (2010). Sexual orientation, gender identity and the refugee determination process. Retrieved from http://ssrn.com/abstract=2276049

LaViolette, N. (2010). Canada's queer community needs to help persecuted sexual minorities. The Globe and Mail. 
Luibheid, E. (2008) Queer/Migration: An unruly body of scholarship. Duke University Press and GLQ: A journal of lesbian and gay studies. http://server2.docfoc.com/uploads/ Z2015/12/26/O1GDzsmxfB/380ef76448abedb93d58002d3b6b3fce.pdf

Luibheid, E. (1998). 'Looking like a Lesbian': The Organization of Sexual Monitoring at the United States-Mexico Border. Journal of the History of Sexuality. 8(3), 477-506.

Retrieved from http://www.jstor.org/stable/3704873

Mellquist, J. (2014). Officially Categorized Queers: Strategies, Risks and Unintentional Effects When Navigating the Swedish Asylum Apparatus. University of Sodertorn. Retrieved from http://www.diva-portal.org/smash/get/diva2:956049/FULLTEXT01.pdf

Mule, N. \& Gates-Gasse, E. (2015). Exploring Asylum Issues. Social Sciences and Humanities Research Council of Canada \& York University. Retrieved from http://envisioninglgbt.blogspot.ca/p/publicationsresources.html

Nash, C. (2014). LGBT neighbourhoods and 'new mobilities': Towards understanding transformations in sexual and gendered urban landscapes. International Journal of Urban and Regional Research. 38(3), 756-772.

Rubin, G. (2002). Out in Theory: The Emergence of Lesbian and Gay Anthropology. University of Illinois Press. 17-47.

Seitz, D. (2016) Limbo life in Canada's waiting room: Asylum-seeker as queer subject. Society and Space, Vol. 0 (0), 1-19.

Segal, L. (2008) After Judith Butler: Identities, Who Needs Them. Subjectivity, Vol. 25 (381 394).

UNHCR. (2017). The 1951 Refugee Convention. Retrieved from http://www.unhcr.org/1951refugee-convention.html

Vertiachykh, M. and Lindroth, M. (2014). The Unwanted: Negotiating the refugeehood in Sweden. Karlstad University, Social and Psychological Studies. Retrieved from http://urn.kb.se/resolve?urn=urn\%3Anbn\%3Ase\%3Akau\%3Adiva-43462 